\title{
Facts and dilemmas in diagnosis of tuberculosis in wildlife
}

M. Maas ${ }^{1,2}$, A.L. Michel ${ }^{3}$, V.P.M.G. Rutten ${ }^{2,3,4 *}$

1 Division of Epidemiology, Department of Farm Animal Health, Faculty of Veterinary Medicine, Utrecht University, Yalelaan 7, 3584 CL Utrecht, the Netherlands

${ }^{2}$ Division of Immunology, Department of Infectious Diseases \& Immunology, Faculty of Veterinary Medicine, Utrecht University, Yalelaan 1, 3584 CL Utrecht, the Netherlands

${ }^{3}$ Department of Veterinary Tropical Diseases, Faculty of Veterinary Science, University of Pretoria, Private Bag X04, Onderstepoort 0110, South Africa

${ }^{4}$ Corresponding author

*E-mail address: v.rutten@uu.nl

Fax: +31 (0)302533555

\section{Abstract}

Mycobacterium bovis, causing bovine tuberculosis (BTB), has been recognized as a global threat at the wildlife-livestock-human interface, a clear "One Health" issue. Several wildlife species have been identified as maintenance hosts. Spillover of infection from these species to livestock or other wildlife species may have economic and conservation implications and infection of humans causes public health concerns, especially in developing countries. Most BTB management strategies rely on BTB testing, which can be performed for a range of purposes, from disease surveillance to diagnosing individual infected animals. New diagnostic assays are being developed for selected wildlife species. This review investigates the most frequent objectives and associated requirements for testing wildlife for tuberculosis at the level of individual animals as well as small and large populations. By aligning those with the available (immunological) ante mortem diagnostic assays, the 
practical challenges and limitations wildlife managers and researchers are currently faced with are highlighted.

\section{Keywords}

Bovine tuberculosis, BTB, Mycobacterium bovis, review, diagnostic assays, cell-mediated immunity, serology, test validation

Contents

1. Introduction

2. The role of diagnostic tests in the management of bovine tuberculosis in wildlife

3. Diagnostic assays that are available

4. Diagnostic approaches to improve assay fitness for purpose

5. Considerations for future test development and applications

6. Conclusion

Acknowledgements

References

\section{Introduction}

Animal health and public health are inextricably intertwined and recognition of this crucial interdependence has led to the multi-disciplinary concept of "One World, One Health, One Medicine". Pathogens that are transmitted between wildlife, livestock and humans represent major challenges for human and animal health, the economic sustainability of agriculture, and the conservation of wildlife [1]. 
In this context, bovine tuberculosis (BTB), caused by Mycobacterium bovis ( $M$. bovis), is a relevant disease threat, impacting on the human-livestockwildlife interface globally [2]. Mycobacterium bovis is a member of the Mycobacterium tuberculosis complex, which also contains other pathogenic mycobacteria like M. tuberculosis [3]. Wildlife species are potential reservoirs of $M$. bovis for domestic animals and humans [4], which may hamper national control and eradication programs that are in place in many (developed) countries [5-7]. Mycobacterium bovis infections have been described in both free-ranging $[8]$ and captive wildlife species $[9,10]$ in various regions of the world. Some of these may act as maintenance hosts, while infection in others is incidental. Animal populations now known to be maintenance host include Eurasian badger (Meles meles, United Kingdom) [11,12], African buffalo (Syncerus caffer) [13], brushtail possum (Trichosurus vulpecula, New Zealand) [14], white-tailed deer (Odocoileus virginianus, United States) [15] and European wild boar (Sus scrofa, Spain)[16]. The spectrum of potential spillover hosts of $M$. bovis is extensive and appears to include a wide range of mammalian species, e.g. gorillas (Gorilla gorilla gorilla) [17], lynx (Lynx pardinus) [18], rhinoceros (Diceros bicornis minor and Ceratotherium simum simum) $[19,20]$, cheetah (Acinonyx jubatus) [21] and lion (Panthera leo) [22]. Since it became known that wildlife can act as reservoirs for $M$. bovis the need for BTB control strategies in these species has been emphasized in a number of countries[8].

In view of the "One Health" concept, the extent of contact and interaction of wildlife reservoirs with domestic animals and humans is one of the main risk 
factors of infection [23]. Direct wildlife-to-human transmission of M. bovis is mainly limited to consumers and processors of (raw) infected wildlife products [24,25], and to keepers of captive wildlife [20]. The indirect BTB transmission from wildlife to humans through livestock is more likely to occur: in developed countries $0-2 \%$ of the tuberculosis cases in humans are caused by BTB [26]; in developing countries these percentages may be much higher and BTB still constitutes a major zoonotic risk there [2,27]. The human-to-wildlife transmission is considered a high risk for especially captive wildlife, that is exposed to human pathogens transmitted by their owners [28] or handlers and the public, e.g. in zoological collections [29-32], wildlife rehabilitation and primate research centers [33] as well as culturally based Asian elephanthuman interactions [34] and the transmission can even occur to free-ranging wildlife as was shown in meerkats (Suricata suricatta) in South Africa [35]. In addition, spillover of BTB from wildlife reservoirs to isolated, small wildlife populations like the Iberian lynx or the black rhinoceros (Diceros bicornis minor), may be reason for concern regarding species conservation [18,36]: it not only causes a potential mortality risk, but may also limit translocation movements [19].

\section{The role of diagnostic tests in the management of bovine}

\section{tuberculosis in wildlife}

One of the pivotal issues of managing wildlife BTB is the availability of diagnostic assays, which is often limited to those developed for domestic animals and humans. On a daily basis, wildlife species are tested for BTB for various purposes, often with diagnostic assays that are accepted due to a lack 
of a better alternative [37]. However, because of the recognition of the role of particular wildlife species like badgers, possums and white-tailed deer in the maintenance of the $M$. bovis infection, as well as its spillover into additional species, an increasing number of studies has been dedicated to the development of diagnostic assays for specific wildlife species, resulting in assay prototypes and partially or fully validated assays [38-41].

\subsection{Fit for purpose principle}

A validation template has been developed by the OIE that specifically requires a test to be fit or suited for its intended purpose [42]. Validation of a 'fit for purpose' test requires specification of the purpose of the test (e.g. as a tool to gather information for surveillance or as a diagnostic, confirmatory test), the type of diagnostic specimen and the target animal species [43]. This 'fit for purpose' principle hinders generalization of diagnostic assays to other species or sample types, e.g. the skin test protocol for cattle is not suitable for pachyderms [19] and sputum samples are suitable for adult humans, but not for animals.

This review examines the currently available and commonly used ante mortem methods for BTB diagnosis, based on their fitness for purpose. The findings are measured against a set of testing objectives which are generally aligned with particular wildlife management objectives and strategies. This approach is intended to point out the discrepancies between the rapidly intensifying activities in the field of wildlife tuberculosis that rely on suitable assays and the present status quo of available (non-)validated assays. 


\subsection{Purposes of testing wildlife for M. bovis infection}

For BTB management, demands towards diagnostic assays differ depending on the context of $M$. bovis infection. Assays must be accurate, simple, affordable and provide a result in time to institute appropriate control measures for that situation [44].

\subsubsection{Surveillance}

According to the OIE, surveillance aims at demonstrating the absence of disease and involves the systematic, continuous collection and analysis of data on the health of wild animal species [45]. Next to this general scanning of wildlife health, a targeted, active surveillance can be conducted. This is a more "snapshot-like" approach focused on a particular pathogen in a specified wildlife population which is classified as healthy, but is considered at risk of exposure to this pathogen from an identified source e.g. screening a wildlife population when positive cases in nearby cattle have been found [46]. Diagnosis of BTB in a deer based on gross lesions (general surveillance) resulted in subsequent targeted sampling of the white-tailed deer population in 1994 in northeastern Michigan (USA), including necropsies and additional culturing [47]. This confirmed infection in the population at a prevalence of nearly $5 \%$ and a BTB management program has been implemented since then for this wildlife reservoir [15].

BTB surveillance of cattle and wildlife is ongoing in many developed countries that seek to maintain a BTB free status, especially those that have established wildlife reservoirs, as early detection of infection may prevent extensive 
spread through the population. In this situation, diagnostic assays are used as tools to determine whether M. bovis is present in a certain area or population, rather than to determine exact prevalence. Surveillance is often passive under these circumstances [48] and involves the help of State and Federal wildlife agencies and hunters [46,49], like in case of the discovery of the first BTB diseased possum in New Zealand [50]. Surveillance generates a continuous flow of potentially large sample sets to the laboratory and requires logistics (i.e. technical simplicity, stability of the test under user conditions, automation) that are easy and robust and are not compromised by long transport times of samples. While the emphasis is on affordability, because of the high throughput, short turn-around times are of less importance [47]. As far as surveillance relies on direct detection methods (necropsies/meat inspection/culturing/histopathology) [51] and serology, it can be used for many wildlife species, provided cross-reactive reagents are available for the latter [52].

\subsubsection{Monitoring}

According to Artois et al., monitoring is restricted to known infected populations, and consists of the systematic recording of epidemiological data, with no other specific purpose than detecting spatial and temporal trends [48]. For $M$. bovis, monitoring may assess the spread, interspecies transmission or the effect of management interventions in wildlife populations, like the culling of badgers [1] or vaccination of possums and badgers [53]. The latter necessitates the use of tests that can differentiate between vaccinated and infected animals (DIVA). 
Monitoring targets specific infected populations and diagnostic methods are needed that have been validated for that species. It is often executed on a smaller scale than surveillance, e.g. wildlife parks instead of countries, but with a more intensive, active approach, like BTB testing of buffaloes using the IFN-y assay and the tuberculin skin test in South African conservation areas [4]. It does not usually include passive surveillance, or passive surveillance plays only a minor role. In general, monitoring is more invasive and expensive than surveillance, with a larger number of animals needing to be tested in a shorter time. This makes monitoring more sensitive to the cost of the test, compared to surveillance, while time constraints are of less importance.

Though diagnostic methods used can identify M. bovis infected individuals, both surveillance and monitoring are not applied to diagnose $M$. bovis infection in a specific, identified individual, but are rather used as a screening tool to determine whether the infectious agent is present in a defined population and area and if so, whether changes occur in prevalence or distribution of the agent in the studied areas and periods of time.

2.2.3 Diagnosis of $M$. bovis infection at individual animal level/in small populations

In contrast with surveillance and monitoring, when testing individual animals and small populations for BTB, the assays have a short-term, true diagnostic application, aiming at confirmation of the $M$. bovis infection status. This includes diagnosis and tracing back of mycobacterial infections in free-ranging and captive wildlife populations including zoological collections, for example 
after confirmation of an initial case in a pot-bellied pig (Sus scrofa vittatus) in a wildlife park [54]. Trace back of $M$. bovis infection of farmed fallow deer (Dama Dama) in Sweden was complicated due to the lack of individual identification [51]. Assessment of the human health risk as a result of close contact with infected wildlife, as described for various captive wildlife species, including elephants, in zoological collections $[30,31,55]$ or for an infected marmoset [28] may be part of these analyses. Diagnosis of BTB in small numbers of individuals has far-reaching implications on the BTB infection status of the respective population and may lead up to control measures like regulatory quarantine or culling, and is therefore traditionally performed with or followed by an accepted gold standard test, i.e. culture. However, since culture is, in most cases, performed most reliably on post mortem tissue samples, there may be a difficult trade-off between loss of a valuable individual, in the context of species conservation, and the consequences of maintaining a potentially BTB infected shedder in the collection. Management choices may differ, as exemplified by BTB infection in Bactrian camels [56] and Asian elephants in zoological collections [57], where respectively culling and medical treatment were chosen.

Diagnosing BTB at the small scale level may benefit from clear classification of the clinical disease status, distinguishing between early infections (preclinical) and active disease. This may provide valuable information with regard to the type of control strategy required [58]. Early detection methods may minimize the spread and the effects of an outbreak. However, a diagnostic assay or testing strategy that could detect the (probably small) proportion of 
highly infectious individuals, i.e. the shedders, can be useful for wildlife species of high value [59], chronically infected populations, as well as wildlife populations with unknown BTB status [60].

\subsubsection{Certification of BTB-free status of animals}

Certification of freedom from BTB, like other infectious diseases, is an official requirement for the safe trade of game meat for human consumption (EU Directive 2003/99/EC)[61,62], as well as for wildlife translocations, e.g. between zoological collections, game parks and game farms [63]. This certification is based on risk assessment involving individual animal and population data relating to the BTB infection status of the particular environment and based on historical or preferably on surveillance data, as well as to a very large extent on diagnostic test results [64]. Since the latter depend on the availability of analytical and diagnostic performance data of the test used, the accuracy of these risk assessments would strongly increase with validated diagnostic methods for specific wildlife species.

No official international protocol for BTB-free certification for wildlife exportation and translocations purposes between zoological collections exists in Europe nor in the USA, and the requirements can differ between countries and states [9]. In Southern Africa, where African buffaloes are a known reservoir for BTB, foot-and mouth disease, theileriosis and brucellosis, strict control measures are in place which require negative test results for all four disease agents prior to movement $[65,66]$. Due to the close phylogenetic relationship to domestic cattle, applicable ante mortem tests such as the 
tuberculin skin test are accepted although not validated. More ideally and to comply with importation regulations, the assay should be animal speciesspecific, have a high sensitivity and a very high specificity and cover a large part of the immune response and test results should be available within a short space of time to avoid long quarantine periods.

If wildlife species are used for meat consumption, the risk assessment for certification will be aided by the use of post mortem examination, whereby the disease free status of the animals must be ensured whenever the meat is destined for the international market. Meat inspection is currently the only method suitable for large-scale screening in slaughtered deer, with final confirmation by culturing [64]. However, as has been shown in wild boar, this may actually not be a very sensitive method [67].

\subsubsection{Research purposes}

Though not directly related to the management of BTB, diagnostic tests providing baseline data also play a crucial role in research in the context of disease ecology, epidemiology, vaccine efficacy or intervention strategies. For example, $M$. bovis infection was measured with an IFN- $\gamma$ ELISA in an epidemiologic study on micro- and macroparasites in buffalo [68] and immunopathogenesis in experimentally infected badgers was assessed with various cell-mediated and serological assays [69] The diagnostic assays can also be used to study the organism, e.g. characterization of (spread of) different strains using mostly DNA fingerprinting and PCR techniques $[54,70]$. Furthermore, experimental infection studies are also conducted to evaluate the performance of a newly developed test or to validate an existing 
diagnostic assay, used in domestic animals, for a wildlife species, of which examples can be found in table 1 . The success and feasibility of these studies depends upon the availability of a suitable test for the wildlife species of interest.

Diagnostic methods in these research settings can be practically as well as financially more demanding, as it often concerns only small populations/study groups for pre-defined periods. They need to be animal species-specific, and often several tests are combined [71].

\section{Diagnostic assays that are available}

A literature review was performed focusing on the search terms: bovine tuberculosis, wildlife (and more specific search terms as deer, buffalo etc), diagnostic assays (and more specific search terms as IFN-y assay, serology, culture etc), and in addition considering cited and citing articles. Diagnostic methods for non-bovine (wildlife) species have been reviewed in 2005 [37] and 2009 [38] as well, and therefore the emphasis of this review is on studies after 2005. Most of the new developments regarding diagnostic methods for M. bovis infection are based on indirect detection, aiming at the assessment of immune response parameters. Table 1 provides an overview of the different studies that have been published on the immunological diagnostic methods for $M$. bovis (and M. tuberculosis) infections in wildlife species. 
Table 1

Summary of the diagnostic tests that have been employed in wildlife. The sensitivity and specificity of diagnostic tests depend on multiple factors, including test populations and test interpretation. This table serves as a general overview of the different studies performed and gives the published estimates of sensitivity and specificity, but readers are referred to the original papers for a more detailed interpretation of these estimates. NE $=$ not estimated, $\mathrm{Se}=$ sensitivity, $\mathrm{Sp}=$ specificity, $\mathrm{SICCT}=$ single intradermal comparative tuberculin test, $\mathrm{DPP}=$ Dual path platform, LPA=lymphocyte proliferation assay, $\mathrm{AB}=$ antibodies, $\mathrm{PPDB}=$ Bovine Purified Protein Derivate, $\mathrm{PPDA}=$ Avian Purified Protein Derivate.

\begin{tabular}{|c|c|c|c|c|c|c|c|}
\hline Species & Test & $\begin{array}{l}\mathrm{Se}^{\mathrm{a}, \mathrm{b}} \text { of } \\
\text { test }\end{array}$ & $\begin{array}{l}\mathrm{Sp}^{\mathrm{a}} \text { of } \\
\text { test }\end{array}$ & $\begin{array}{l}\text { Number of } \\
\text { animals } \\
\text { tested }\end{array}$ & $\begin{array}{l}\text { Infection: natural } \\
\text { (N)/experi-mental } \\
\text { (E) }\end{array}$ & Details & References \\
\hline \multirow[t]{9}{*}{ Badger (Meles meles) } & IFN- $\gamma$ assay & $80.9 \%$ & $93.6 \%$ & 235 & $\mathrm{~N}$ & $\begin{array}{l}\text { Whole blood; } \\
\text { monoclonal AB; } \\
\text { PPDB-PPDA } \\
\text { comparison }\end{array}$ & [106] \\
\hline & Brock ELISA & $48.9 \%$ & $93.6 \%$ & 235 & $\mathrm{~N}$ & & \\
\hline & RT qPCR & $70.6 \%$ & $90.7 \%$ & 247 & & $\begin{array}{l}\text { PPDB-PPDA } \\
\text { comparison; } \\
\text { specific antigens }\end{array}$ & [124] \\
\hline & Rapid test & $50.7 \%$ & $93.1 \%$ & 1532 & $\mathrm{~N}$ & & {$[140]$} \\
\hline & $\begin{array}{l}\text { Brock } \\
\text { STAT-PAK }\end{array}$ & $49.2 \%$ & $93.1 \%$ & 1464 & $\mathrm{~N}$ & $\begin{array}{l}\text { Higher Se for } \\
\text { animals with } \\
\text { severe tuberculosis }\end{array}$ & [59] \\
\hline & Brock ELISA & $68 \%$ & $\mathrm{NE}$ & 128 & $\mathrm{~N}$ & MPB83 antigen & {$[156]$} \\
\hline & MAPIA & $48.7 \%$ & $88.0 \%$ & 178 & $\mathrm{~N}$ & & [138] \\
\hline & Rapid test & $52.6 \%$ & $95.0 \%$ & 178 & $\mathrm{~N}$ & & \\
\hline & Brock ELISA & $47.4 \%$ & $89.0 \%$ & 178 & $\mathrm{~N}$ & MPB83 antigen & \\
\hline $\begin{array}{l}\text { Possum (Trichosurus } \\
\text { Vulpecula) }\end{array}$ & Rapid test & $44.7 \%$ & 85.7 & 129 & $\mathrm{~N}$ & & {$[140]$} \\
\hline \multirow[t]{3}{*}{ Fallow deer (Dama dama) } & $\begin{array}{l}\text { CervidTB } \\
\text { STAT-PAK }\end{array}$ & 80.1 & $\mathrm{NE}$ & 134 & $\mathrm{~N}$ & & [167] \\
\hline & $\begin{array}{l}\text { CervidTB } \\
\text { STAT-PAK }\end{array}$ & $91 \%$ & $91 \%$ & 139 & $\mathrm{~N}$ & & [139] \\
\hline & $\begin{array}{l}\text { Dual path } \\
\text { platform VetTB } \\
\text { test }\end{array}$ & $91 \%$ & $99 \%$ & 139 & $\mathrm{~N}$ & & \\
\hline \multirow[t]{5}{*}{$\begin{array}{l}\text { Red deer (Cervus elaphus } \\
\text { elaphus) }\end{array}$} & RT qPCR & $78.6 \%$ & $97.5 \%$ & 15 & E & $\begin{array}{l}\text { Red deer } \times \text { elk } \\
\text { hybrids }\end{array}$ & [71] \\
\hline & $\begin{array}{l}\text { IFN- } \gamma \text { ELISA } \\
\text { (Cervigam) }\end{array}$ & $70 \%$ & $100 \%$ & 15 & E & $\begin{array}{l}\text { Red deer } \times \text { elk } \\
\text { hybrids }\end{array}$ & \\
\hline & LPA & $65.7 \%$ & $92.5 \%$ & 15 & $\mathrm{E}$ & $\begin{array}{l}\text { Red deer } \times \text { elk } \\
\text { hybrids }\end{array}$ & \\
\hline & $\begin{array}{l}\text { CervidTB } \\
\text { STAT-PAK }\end{array}$ & $86.5 \%$ & $83.8 \%$ & 157 & $N+E$ & $\begin{array}{l}\text { Lower Se for only } \\
\text { natural infected } \\
\text { deer }\end{array}$ & [149] \\
\hline & DPP VetTB test & $84.6 \%$ & $91.4 \%$ & 157 & $N+E$ & $\begin{array}{l}\text { Lower Se for only } \\
\text { natural infected } \\
\text { deer }\end{array}$ & \\
\hline \multirow[t]{3}{*}{ Elk (Cervus elaphus nelsoni) } & $\begin{array}{l}\text { Intradermal } \\
\text { tuberculin test }\end{array}$ & $88 \%$ & $69 \%$ & 60 & $\mathrm{~N}$ & Single cervical test & [95] \\
\hline & $\begin{array}{l}\text { CervidTB } \\
\text { STAT-PAK }\end{array}$ & $82 \%$ & $93 \%$ & 175 & $\mathrm{~N}$ & & [139] \\
\hline & $\begin{array}{l}\text { Dual path } \\
\text { platform VetTB } \\
\text { test }\end{array}$ & $79 \%$ & $98 \%$ & 175 & $\mathrm{~N}$ & & \\
\hline \multirow[t]{4}{*}{ Reindeer (Rangifer tarandus) } & $\begin{array}{l}\text { IFN- } \gamma \text { ELISA } \\
\text { (Cervigam) }\end{array}$ & $\mathrm{NE}$ & $90 \%$ & 51 & $\mathrm{~N}$ & $\begin{array}{l}\text { PPDB-PPDA } \\
\text { comparison }\end{array}$ & {$[180]$} \\
\hline & ELISA & $100 \%$ & $50 \%$ & 15 & $\mathrm{E}$ & $\begin{array}{l}\text { lipoarabinomannan } \\
\text { (LAM)-enriched } \\
\text { mycobacterial } \\
\text { antigen from } M \text {. } \\
\text { bovis strain } \\
\text { 95-1315 }\end{array}$ & [147] \\
\hline & Immunoblot & $90.9 \%$ & $50 \%$ & 15 & $\mathrm{E}$ & $\begin{array}{l}\text { Antigen: } \\
\text { whole-cell sonicate } \\
\text { (WCS) of M. bovis } \\
\text { strain } 95-1315\end{array}$ & \\
\hline & MAPIA & $100 \%$ & $85 \%$ & 34 & E & Including MPB83 & \\
\hline
\end{tabular}


Table 1 (Continued)

\begin{tabular}{|c|c|c|c|c|c|c|c|}
\hline Species & Test & $\begin{array}{l}\mathrm{Se}^{\mathrm{a}, \mathrm{b}} \text { of } \\
\text { test }\end{array}$ & $\begin{array}{l}\mathrm{Sp}^{\mathrm{a}} \text { of } \\
\text { test }\end{array}$ & $\begin{array}{l}\text { Number of } \\
\text { animals } \\
\text { tested }\end{array}$ & $\begin{array}{l}\text { Infection: natural } \\
(\mathrm{N}) / \text { experi-mental } \\
\text { (E) }\end{array}$ & Details & References \\
\hline \multirow{8}{*}{$\begin{array}{l}\text { White-tailed deer (Odocoileus } \\
\text { virginianus) }\end{array}$} & Rapid test & $75 \%$ & $98.9 \%$ & 463 & $N+E$ & & [140] \\
\hline & $\begin{array}{l}\text { CervidTB } \\
\text { STAT-PAK }\end{array}$ & $56 \%$ & $98.9 \%$ & 556 & $\mathrm{~N}$ & Whole blood & [137] \\
\hline & $\begin{array}{l}\text { CervidTB } \\
\text { STAT-PAK }\end{array}$ & $54.5 \%$ & $98.1 \%$ & 746 & $\mathrm{~N}$ & Serum & \\
\hline & MAPIA & $68.2 \%$ & $97.1 \%$ & 749 & $\mathrm{~N}$ & & \\
\hline & Immunoblot & $46.2 \%$ & $92.5 \%$ & 346 & $\mathrm{~N}$ & $\begin{array}{l}\text { M.bovis whole-cell } \\
\text { sonicate }\end{array}$ & \\
\hline & & $55 \%$ & $99.3 \%$ & 691 & $\mathrm{~N}$ & MPB83 antigen & \\
\hline & ELISA & $66.7 \%$ & $95.1 \%$ & 341 & $\mathrm{~N}$ & $\begin{array}{l}\text { Lipoarabinomannan- } \\
\text { enriched antigen } \\
\text { from } M \text {. bovis strain } \\
95-1315 \text {; } \\
\Delta \mathrm{OD} \geq 0.25\end{array}$ & \\
\hline & ELISA & $58.3 \%$ & $97.3 \%$ & 341 & $\mathrm{~N}$ & $\begin{array}{l}\text { Lipoarabinomannan- } \\
\text { enriched antigen } \\
\text { from } M \text {. bovis strain } \\
95-1315 \text {; } \\
\Delta \mathrm{OD} \geq 0.3\end{array}$ & \\
\hline \multirow[t]{2}{*}{ Multiple cervid species } & $\begin{array}{l}\text { CervidTB } \\
\text { STAT-PAK }\end{array}$ & $85.7 \%$ & $94.8 \%$ & 432 & $\mathrm{~N}$ & $\begin{array}{l}\text { Roe deer, fallow } \\
\text { deer, red deer }\end{array}$ & [181] \\
\hline & FPA & $81 \%$ & $80 \%$ & 31 & $\mathrm{~N}$ & $\begin{array}{l}\text { For Se: positive or } \\
\text { suspect result. Two } \\
\text { FPA suspect results } \\
\text { were culture } \\
\text { negative, but } \\
\text { histopathology } \\
\text { suspect }\end{array}$ & [155] \\
\hline \multirow[t]{3}{*}{ Bison (Bison bison athabascae) } & FPA & $67 \%$ & $34 \%$ & 56 & $\mathrm{~N}$ & & [142] \\
\hline & MAPIA & $92 \%$ & $97 \%$ & 82 & $\mathrm{~N}$ & & \\
\hline & Rapid test & $67 \%$ & $99 \%$ & 82 & $\mathrm{~N}$ & & \\
\hline \multirow[t]{4}{*}{ Buffalo (Syncerus caffer) } & $\begin{array}{l}\text { Modified } \\
\text { QuantiFERON- } \\
\text { TB Gold } \\
\text { (In-Tube) }\end{array}$ & $98 \%$ & $96 \%$ & 174 & $\mathrm{~N}$ & $\begin{array}{l}\text { Compared to the } \\
\text { SICCT; Cut-off } \\
\text { value IFN- } \gamma \text { optical } \\
\text { density difference } \\
\text { antigen- } \\
\text { mitogen } \geq 66 \mathrm{pg} / \mathrm{ml}\end{array}$ & [99] \\
\hline & IFNg ELISA & $92.6 \%$ & $68.3 \%$ & 493 & $\mathrm{~N}$ & $\begin{array}{l}\text { Standard test } \\
\text { interpretation }\end{array}$ & [39] \\
\hline & & $93.9 \%$ & $85.4 \%$ & 493 & $\mathrm{~N}$ & $\begin{array}{l}\text { Optimal overall } \\
\text { test validity }\end{array}$ & \\
\hline & $\begin{array}{l}\text { Rapid test } \\
\text { BovidTB } \\
\text { STAT-PAK } \\
\text { Rapid test } \\
\text { Anigen }\end{array}$ & $23 \%$ & $94 \%$ & 200 & $\mathrm{~N}$ & $\begin{array}{l}\text { Inclusion of suspect } \\
\text { reactions increased } \\
\text { Se, but lowered Sp } \\
\text { Inclusion of suspect } \\
\text { reactions increased } \\
\text { Se, but lowered Sp }\end{array}$ & {$[60]$} \\
\hline \multirow[t]{4}{*}{ Wild boar (Sus scrofa) } & Rapid test & $76.6 \%$ & $97.3 \%$ & 177 & $\mathrm{~N}$ & $\begin{array}{l}\text { Se higher in } \\
\text { animals with } \\
\text { lesions }\end{array}$ & [140] \\
\hline & ELISA & $72.6 \%$ & $96.4 \%$ & 185 & $\mathrm{~N}$ & $\begin{array}{l}\text { Se }+ \text { Sp dependent } \\
\text { on cut-of value; } \\
\text { PPDB antigen }\end{array}$ & [171] \\
\hline & ELISA & $79.2 \%$ & $100 \%$ & 200 & $\mathrm{~N}$ & PPDB & [182] \\
\hline & DPP TB & $89.6 \%$ & $90.4 \%$ & 200 & $\mathrm{~N}$ & & \\
\hline \multirow{3}{*}{$\begin{array}{l}\text { Elephant, African (Loxodonta } \\
\text { africana) and Asian (Elephas } \\
\text { maximus) }\end{array}$} & $\begin{array}{l}\text { ElephantTB } \\
\text { STAT-PAK }\end{array}$ & $100 \%$ & $95.2 \%$ & 173 & $\mathrm{~N}$ & M. tuberculosis & [143] \\
\hline & MAPIA & $100 \%$ & $100 \%$ & 173 & $\mathrm{~N}$ & M. tuberculosis & \\
\hline & DPP VetTB & $100 \%$ & $100 \%$ & 173 & $\mathrm{~N}$ & M. tuberculosis & \\
\hline \multirow[t]{2}{*}{ Lion (Panthera leo) } & $\begin{array}{l}\text { Intradermal } \\
\text { tuberculin test }\end{array}$ & $86.5 \%$ & $81.3 \%$ & 84 & $\mathrm{~N}$ & $\begin{array}{l}\text { Single Intradermal } \\
\text { Cervical Test }\end{array}$ & [22] \\
\hline & ELISA & $46.1 \%$ & NE & 26 & $\mathrm{~N}$ & MPB70 antigen & $\begin{array}{l}\text { As referred } \\
\text { to in }[22]\end{array}$ \\
\hline
\end{tabular}


Table 1 (Continued)

\begin{tabular}{|c|c|c|c|c|c|c|c|}
\hline Species & Test & $\begin{array}{l}\mathrm{Se}^{\mathrm{a}, \mathrm{b}} \text { of } \\
\text { test }\end{array}$ & $\begin{array}{l}\mathrm{Sp}^{\mathrm{a}} \text { of } \\
\text { test }\end{array}$ & $\begin{array}{l}\text { Number of } \\
\text { animals } \\
\text { tested }\end{array}$ & $\begin{array}{l}\text { Infection: natural } \\
\text { (N)/experi-mental } \\
\text { (E) }\end{array}$ & Details & References \\
\hline \multirow[t]{2}{*}{ Meerkat (Suricata suricatta) } & Rapid test & $43 \%$ & $85 \%$ & 110 & $\mathrm{~N}$ & Bayesian estimates & [81] \\
\hline & MAPIA & $90 \%$ & $48 \%$ & 110 & $\mathrm{~N}$ & Bayesian estimates & \\
\hline Alpaca (Lama pacos) & Rapid test & $71 \%$ & $98 \%$ & 156 & $\mathrm{~N}$ & $\begin{array}{l}\text { M. bovis or } M \text {. } \\
\text { microti }\end{array}$ & [183] \\
\hline Alpaca (Lama pacos) & $\begin{array}{l}\text { Dual-path } \\
\text { platform }\end{array}$ & $74 \%$ & $98 \%$ & 156 & $\mathrm{~N}$ & & \\
\hline Llama (Lama glama) & Rapid test & $77 \%$ & $94 \%$ & 175 & $\mathrm{~N}$ & & [183] \\
\hline Llama (Lama glama) & $\begin{array}{l}\text { Dual-path } \\
\text { platform }\end{array}$ & $77 \%$ & $98 \%$ & 175 & $\mathrm{~N}$ & & \\
\hline $\begin{array}{l}\text { Dromedary (Camelus } \\
\text { dromedarius) }\end{array}$ & StatPak, MAPIA & & & & $\mathrm{N}$ & $\begin{array}{l}\text { Both tests correctly } \\
\text { identified } 3 \text { culture } \\
\text { positive dromedary }\end{array}$ & [184] \\
\hline \multirow[t]{2}{*}{ Multiple camelid species } & Rapid test & $63 \%$ & $90 \%$ & 87 & $\mathrm{~N}$ & $\begin{array}{l}\text { Alpaca, llama. } M \text {. } \\
\text { microti infection }\end{array}$ & [141] \\
\hline & MAPIA & $88 \%$ & $97 \%$ & 87 & $\mathrm{~N}$ & $\begin{array}{l}\text { Alpaca, llama. } M \text {. } \\
\text { microti infection }\end{array}$ & \\
\hline $\begin{array}{l}\text { Chacma Baboon (Papio } \\
\text { ursinus) }\end{array}$ & \multicolumn{2}{|c|}{ IFN- $\gamma$ assay100\% (2/2) } & $100 \%$ & 51 & $\mathrm{~N}$ & $\begin{array}{l}\text { QuantiFERON-TB } \\
\text { Gold system; } \\
\text { in-tube tb antigen } \\
\text { stimulation; Sp } \\
\text { partly based on } \\
\text { TST; } \text { M. tuberculosis }\end{array}$ & [185] \\
\hline $\begin{array}{l}\text { Rhesus monkey (Macaca } \\
\text { mulatta) }\end{array}$ & $\begin{array}{l}\text { PrimaTB } \\
\text { STAT-PAK }\end{array}$ & $89.7 \%$ & $98.6 \%$ & 243 & E & $\begin{array}{l}5 \text { animals used as } \\
\text { pre-inoculation } \\
\text { control group; } M \text {. } \\
\text { tuberculosis }\end{array}$ & [128] \\
\hline $\begin{array}{l}\text { Cynomolgus monkey (Macaca } \\
\text { fascicularis) }\end{array}$ & $\begin{array}{l}\text { PrimaTB } \\
\text { STAT-PAK }\end{array}$ & $93.8 \%$ & $100 \%$ & 46 & $\mathrm{E}$ & M. tuberculosis & \\
\hline $\begin{array}{l}\text { African Green monkey } \\
\text { (Cercopithecus aethiops } \\
\text { sabaeus) }\end{array}$ & $\begin{array}{l}\text { PrimaTB } \\
\text { STAT-PAK }\end{array}$ & $80 \%$ & $99.2 \%$ & 133 & $\mathrm{E}$ & M. tuberculosis & \\
\hline Various monkey species & $\begin{array}{l}\text { IFN- } \gamma \text { assay } \\
\text { (PRIMAGAM) }\end{array}$ & $100 \%$ & $100 \%$ & 343 & $\mathrm{E}$ & $\begin{array}{l}225 \text { Rhesus, } 82 \\
\text { cynomolgus, } 19 \\
\text { chimpanzees, } 17 \\
\text { new world } \\
\text { monkeys; } M \text {. } \\
\text { tuberculosis }\end{array}$ & [33] \\
\hline Various monkey species & $\begin{array}{l}\text { IFN- } \gamma \text { assay } \\
\text { (PRIMAGAM) }\end{array}$ & $68 \%$ & $97 \%$ & 64 & $\mathrm{~N}$ & $\begin{array}{l}\text { cynomolgus and } \\
\text { rhesus monkeys; } \\
\text { for cynomolgus } \\
\text { macaques different } \\
\text { cut-of levels for the } \\
\text { PRIMAGAM test } \\
\text { should be } \\
\text { considered; } M \text {. } \\
\text { bovis }\end{array}$ & {$[100]$} \\
\hline
\end{tabular}

a Sensitivity and specificity of tests are calculated by comparing with mycobacterial culture results, unless stated otherwise.

b Some studies have used only small numbers of confirmed positive animals.

c STAT-PAK tests are also known as lateral-flow immunochromatographic tests or rapid tests. 


\subsection{Direct assays}

Diagnostic assays may be based on the direct detection of the infectious agent. Since this is independent of the host species, they are generally well established for the different Mycobacteria spp.. Direct identification of the agent may be by microscopic demonstration of acid-fast bacilli in various samples, bacterial culture and the polymerase chain reaction (PCR), whereby the latter is also useful for differentiation between Mycobacterium spp. [43] as was used e.g. in elk [72] and lynx [18]. Direct microscopic smear examination is a fast, inexpensive method and can provide a presumptive diagnosis, especially when clinical signs and lesions are present. Its sensitivity has been reported to be variable depending on the wildlife species and severity of infection and ranged from $55.6 \%$ in wild boar [67] to $90 \%$ in white-tailed deer [73], while in lions there was an apparent absence of acid-fast bacilli in culture positive organs [22]. On the other hand, in combination with gross pathological examination, direct microscopic smear examination was found highly sensitive (95\%) in infected wild boar and recommended as a useful tool for surveys and game meat inspection schemes [67].

Gross pathology observed post mortem in tissues, organs and carcasses due to $M$. tuberculosis complex infection is based on the typical granulomatous appearance of tuberculous lesions in most wildlife species. The sensitivity of gross pathology is higher in advanced stages of the diseases, but has been reported to differ from $63 \%$ in African buffalo [74], $75 \%$ in white-tailed deer [75] to $93 \%$ in elk [76]. In contrast, $M$. bovis infection is pre-clinical in most Eurasian badgers and hence gross pathological examination is generally 
insensitive [77]. Likewise, culture positive hyena either showed no visible lesions or lesions were limited to mesenteric lymph nodes and are easily overlooked (Bengis, pers. comm.)

Culture of mycobacteria can be performed using different culture systems and different decontamination protocols have been described (e.g. $[78,79])$. It is still recognized as the gold standard for diagnosis of mycobacterial infections, and is as such used for comparison when validating new assays. M.bovis isolates can be used for subsequent DNA typing, which is a valuable contribution to assess the epidemiology of BTB [80]. Culture has a high specificity throughout different studies and its sensitivity is generally estimated rather high, especially in the presence of lesions in the culture tissues, e.g. in white-tailed deer [73]. However, if sample types with no proven involvement in the BTB pathogenesis are chosen, a lower sensitivity must be expected, e.g. in tracheal washes in meerkats [81]. Additionally, it is complicated by intermittent shedding of bacteria, as confirmed in cattle [82] and badgers [83]. A further disadvantage is that culture requires up to 6-12 weeks before a result is obtained $[43,79]$.

PCR has been the most studied of the different molecular techniques that exist for the species identification of Mycobacterium [43]. It is widely used in all wildlife species for differentiation of mycobacteria of the $M$. tuberculosis complex from non-tuberculous mycobacteria, as well as for more specific differentiation of $M$. bovis from other members of the M. tuberculosis complex $[52,72,84,85]$. It can be performed after culture or directly in the suspect 
samples [34], but the latter approach demands a sufficiently high bacterial load, as obviously it is influenced by irregular shedding of the bacteria [83]. Up till now, it produced variable and less than satisfactory results for the use in animals, particularly in specimens containing low number of bacilli [81]. To improve the reliability of PCR as a diagnostic method, standardization of the technique will be required [43].

For human TB diagnostics, culture and/or PCR is often performed on sputum samples [43]. This approach is a routine procedure for elephants (trunk washes) [57] and has also been used for tracheal washings of possums [86] and meerkats [81], though with limited sensitivity. In most wildlife species however, culturing, with possible subsequent PCR, has mainly been used as post mortem method, starting from samples from affected lymph nodes and other tissues (e.g. [87]). Culture and PCR have not been included in table 1, that focuses on ante mortem methods.

\subsection{Indirect assays}

\subsubsection{Immune response}

Tuberculosis is primarily an infection of the respiratory tract, where the agent uses the macrophage as primary host cell for intracellular replication [88], though for carnivores and omnivores, the primary infection route may also be via the gastro-intestinal tract i.c. the head and mesenteric lymph nodes. Early after infection, innate protective responsiveness and cell-mediated immune responses $(\mathrm{CMI})$ are activated and are generally believed to play a major role in controlling the infection [89]. As the disease progresses, sometimes after 
prolonged pre-clinical periods, the humoral response is activated and antibody titers increase [88]. The time frame of this shift from CMI to the humoral response depends on many factors, like host species and immunity, initial infection dose, re-infection etc. The measurement of either or both stages of the immune response can be used for immunological diagnosis of $M$. bovis infection and new developments in diagnosis of $M$. bovis infection in wildlife are reviewed below for $\mathrm{CMI}$ and the humoral response separately.

\subsubsection{Cell mediated immunity}

Activation of lymphocytes that produce Th1 type cytokines, the most prominent of which is IFN- $\gamma$, is of major importance as a defence mechanism of the body against $M$. bovis infection. Activating these lymphocytes can result in a delayed type hypersensitivity reaction in vivo [90], including production of cytokines, that can be mimicked in stimulated blood cultures in vitro. Based on this knowledge, CMI related diagnostic tests have been developed, that in general have the advantage to become positive in an early stage of the disease, but that may fade away when BTB progresses [91,92].

\subsubsection{Tuberculin skin test}

The in vivo measurement of a delayed type hypersensitivity induced by Purified Protein Derivate (PPD), i.e. the tuberculin skin test, has long been the standard diagnostic test for tuberculosis in human and cattle [90]. PPDB is produced from heat processed $M$. bovis cultures, whereas PPDA, used as a control for exposure to environmental, non-tuberculous mycobacteria, is $M$. avium subsp. avium derived [92]. For BTB diagnosis in cattle, the tuberculin 
skin test is still the test of choice as prescribed by the OIE, with the IFN-Y assay as alternative test [43]. The skin test has been used as an individual animal test in support of eradicating BTB from infected herds in many countries worldwide [93]. However, depending on test interpretation, stage and severity of disease, BTB prevalence, cross-reacting organisms and other factors, sensitivity and specificity are highly variable and estimates in cattle range from respectively $52-100 \%$ and $75.5-100 \%$ (reviewed in $[92,94]$ ). In its original fashion, using PPD's as stimulants, it is unable to differentiate between infected or BCG vaccinated animals [53]. Though its applicability has been evaluated for wildlife species like elk [95], lions [22] and deer [96], the tuberculin skin test has not been validated and standardized for many exotic species [97]. The tuberculin skin test has severe limitations when applied to free-ranging wildlife [8]: i.e. optimal tuberculin doses are often unknown, recapture of animals after 72 hours is at the least impractical if not impossible [38], exposure to environmental mycobacteria may cause high background values $[84,92]$ and in species belonging to the pachyderms the nature of the skin renders the intradermal test impractical [19].

\subsubsection{IFN-y release assays}

The IFN- $\gamma$ release assays are in vitro assays, based on Th1 cell reactivity like in the intradermal skin test. Whole blood or isolated peripheral blood mononuclear cells (PBMCs) are stimulated in the presence or absence of mycobacterial antigens (avian or bovine PPD or other more specific antigens of Mycobacterium spp), that induce previously sensitized T-cells to produce IFN-y. Quantification of this IFN- $\gamma$ is performed in a sandwich ELISA or 
ELISPOT. Interpretation criteria for positive reactors may be adjusted, depending on the test purpose and disease prevalence [98]). For cattle, the IFN-y ELISA (Bovigam) is approved under EU directive 64/432 EEC annex B as ancillary test for BTB diagnosis and studies in cattle have shown that the sensitivity of the bovine IFN- $\gamma$ assay varied between $73.0 \%$ and $100 \%$, and the specificity between $85.0-99.6 \%$ (reviewed in [92]). For selected bovid wildlife species, the Bovigam has been provisionally validated [39]. New commercial whole blood IFN-y assays are also available for other wildlife species, of which PRIMAGAM (Prionics) received provisional USDA licensure for use in nonhuman primates [58]. Modification of a human TB assay was recently reported to show promising results when used in African buffalo [99] As further illustrated in table 1, IFN-y assays are still being developed of which some results are promising [33], though not always confirmed in other studies [100].

The ELISPOT is a relatively new IFN-y release assay, which was used for example to determine BCG vaccination efficacy in badgers [101]. The ELISPOT requires the isolation of a known number of PBMC and measures their IFN-Y production after antigen stimulation by counting the "spots" of captured IFN-y, representing cells producing it $[102,103]$. In a study in humans, ELISPOT had a higher sensitivity compared to the IFN-y ELISA, but its results showed a more rapid decline in sensitivity than the IFN- $y$ ELISA in case of delays in sample processing [104]. 
The identification of immunodominant proteins unique to the $M$. tuberculosis complex, for example ESAT6 and CFP10, as stimulatory antigens in the IFN-Y assay may increase test specificity [105], though sensitivity may be less than with PPD's alone, as was shown in badgers [106]. ESAT6 and CFP10 have also shown potential to circumvent cross-reactivity that could lead to misclassification [107], which was noticed for example in cattle co-infected with other mycobacteria, when PPD's were used [108]. Potentially these proteins, or other newly discovered immunodominant proteins [109-111], are able to differentiate infected from vaccinated animals (DIVA), hence can also be used in Bacillus Calmette-Guérin (BCG) vaccinated populations [105,112114].

Like the skin test, the IFN-y release assay has time limits because of decreasing CMI responsiveness during progression of disease, as was also shown in deer [71]. Its test result is known to be influenced by the time lapse between collection of samples and their processing [115,116], though samples may be potentiated by addition of IL-12 [117]. IFN- $\gamma$ release assays are laboratory based techniques [92], but the development of 'in tube` or 'in plate' techniques may increase the ease of use [93]. The assay can be performed with either whole blood or PBMC. However, the effort of PBMC isolation may not be necessary as results of the assay with whole blood or PBMC were found to be comparable in humans [104]. The Bovigam assay used in cattle is performed using whole blood [118]. 
In humans and cattle, antigen-specific IFN-y responsiveness decreased over time during anti-tuberculosis treatment [119-121], showing the potential of the IFN- $\mathrm{y}$ release assay as a monitoring method for treatment. However, this relation between treatment and IFN-y decline was not found in other human studies $[122,123]$.

\subsubsection{3 qRT-PCR}

The quantitative real time polymerase chain reaction ( $q P C R$ ) amplifies and simultaneously quantifies one or more specific sequences in a DNA sample, by measuring (incorporated) fluorescent signals. It is often combined with reverse transcription ( $q R T-P C R$ ) to quantify mRNA, as is the case when assessing the production of IFN- $\gamma$, and optionally other cytokines. This IFN- $\gamma$ mRNA presence was shown to correlate well with IFN-ץ protein production in deer, as shown in table 1 [71].

The qRT-PCR may be adapted for the use in closely related species by designing, testing and optimising consensus sequences for primers. It can also be easily applied to non-related species if IFN-y sequence information is available [71,124]. The qRT-PCR is a laboratory based technique and compared to other assays in this review, relatively advanced technical equipment is needed. Its sensitivity can be affected by delays in the processing of blood, causing significant, selective changes in cytokine mRNA expression, as was shown in humans [104]. 


\subsubsection{Serology}

Serological tests distinguish between animals that do and do not have circulating antibodies against $M$. bovis. A positive test result may indicate: 1) present infection; 2) immunity to a previous infection; 3) cross-reaction with a shared antigen from other infection agents; 4) the presence of maternal antibodies or 5) antibodies present as a result of vaccination (e.g. with BCG). A negative test result may indicate: 1) the individual is not infected and was never before; 2) the infection is recent and detectable antibody responses have not yet developed; 3) priming has taken place in the past but antibodies are not present anymore in detectable quantities or 4) the host is or was infected, but was not capable of producing antibodies against the infection [125].

Animals with progressive disease tend to gradually lose the capacity to mount CMI and develop serological responses. Compared to cattle, disease progression will be more often encountered in infected free-ranging wildlife species due to the absence of routine testing and test-and-slaughter policy. For these animals, antibody-based diagnosis may be of greater importance [89]. However, when ELISA based tests are used to obtain a TB free population, in course of time, with fewer animals in an advanced stage of infection, the sensitivity will decrease [126].

Serological assays have advantages in terms of logistics, due to stability of antibodies during transport, storage and handling, which reduces the costs and increases the ease of application. Their results, however, may also vary 
depending on the state of the samples: samples that were hemolyzed or lipemic had a statistically significant reduction in sensitivity, but not in specificity, compared to "normal" samples in the BrockTB STAT-PAK Assay [59]. In the past, their sensitivity used to be too low, but the use of early antigens for recognition and the development of new techniques has improved sensitivity [127] to an extent that serological responses in non-human primates and in cervids were found positive starting from 4 weeks post experimental infection $[128,129]$.

\subsubsection{ELISA and immunochromatographic tests}

Enzyme-linked immunosorbent assays (ELISAs) were initially developed with PPD's as antigens, but suffered from low specificity due to cross-reactivity [130]. For cattle, the specificity was improved by the use of more specific antigens (MPB83, MPB70, etc) [131-133]. The MPB70 ELISA, in particular, has been used in various studies to determine the prevalence of $M$. bovis in wildlife populations $[52,134]$, but the value of the results of these studies may be limited, as the ELISA was not validated for most of these wildlife species.

To improve sensitivity of serological assays, new techniques have been developed, amongst which is the lateral-flow immunochromatographic test, an animal-side test that uses a cocktail of a limited number of antigens [135]. To date, this technique is commercially available for elephants, several deer and camelid species, badgers, and non-human primates (known as STAT-PAK, Chembio Diagnostic Systems, Inc., Medford, NY, USA). Results of this assay in studies with various wildlife species are listed in table 1, and show that 
study outcomes vary between the species, which may be explained by different immune responses between species. In the USA, this test format is licensed by the USDA for elephants and nonhuman primates, and in the United Kingdom for badgers [43].

Another confirmative serological technique is multi-antigen print immunoassay (MAPIA), which can be used to determine the species-specific, immunological profile to $M$. bovis infection. This specialized technique is based on immobilization of a number of individual antigens onto nitrocellulose membranes by semi-automated microspraying, followed by standard chromogenic immunodevelopment [136]. It has aided in improvement of the various lateral-flow immunochromatographic tests and in the design of the dual-path platform assay (DPP). The DPP is a next generation immunochromatographic test, which makes use of a dual-flow pathway. As shown in table 1, it has been tested for various wildlife species in comparison to the lateral-flow immunochromatographic test, and in general, it gave equal or slightly higher specificity $[81,137,138]$.

Variation between and within species in the recognition of antigens has been found $[139,140]$, as well as different affinities of antibodies to test reagents. MPB83 is an early antigen that, in general, is best recognized in species like Eurasian badgers, white-tailed deer, brushtail possums, cervids and new world camelids $[69,129,140,141]$. Likewise, ESAT6 and CFP10 are well recognized $[97,139,142-144]$. Combining antigens for the detection of $M$. bovis specific antibodies in wells of ELISA plates may increase sensitivity of 
the assay, without significantly affecting the specificity [145], however total serologic response may be lower than those calculated by the sum of the activities of their components [136].

There may also be potential for the serological techniques to discriminate between M. bovis-infected and BCG-vaccinated individuals $[138,146]$, or to monitor antibody responses during treatment $[97,135]$. Antibody responses to M. bovis infection in, for example, wild boar were positively associated with advanced disease, i.e. with the presence of extensive gross lesions [140]. Similar observations have been previously made for other host species, e.g. badgers and reindeer $[69,147]$. Given that individuals with advanced disease are also more likely to be excreting [148], these animals may be important targets for control programs.

The lateral-flow immunochromatographic test did not show cross-reaction in small numbers of wild boar exposed to $M$. avium infection or deer exposed to Mycobacterium avium subspecies paratuberculosis, supporting the high specificity of the assay [140]. However, this was contradicted in a study in farmed red deer, which showed that vaccination against paratuberculosis and subsequent skin testing adversely affected the specificity of the CervidTB STAT-PAK and DPP VetTB test, as did natural infection with $M$. avium subsp. paratuberculosis for the specificity of the CervidTB STAT-PAK test [149]. 


\subsubsection{Other methods}

The multiplex chemiluminescence immunoassay is a new diagnostic assay that can detect antibodies specific to $M$. bovis [150]. This assay employs up to 25 individual mycobacterial antigens that are printed in small dots in a single well in a 96-well plate array format and could thus be useful for large-scale testing. Individual serum samples are added to each well. The chemiluminescent signal is captured by digital imaging. This assay has shown to have a sensitivity of $93.1 \%$ and a specificity of $98.4 \%$ in cattle, also detecting antibodies as early as 2 weeks post infection [150], though under field conditions, slightly lower sensitivity and specificity were achieved, depending on the cut-off level [126]. It has also shown to have high sensitivity $(98.3 \%)$ and specificity $(100 \%)$ in detecting $M$. bovis infection in goats $(n=180)[151]$. Other assays based on similar principals involve a single antigen chemiluminescence assay with magnetic iron beads (SeraLyte-Mbv тм [152]) and the multiplex microbead immunoassay, based on Luminex technology, that was developed in an experimental nonhuman primate model and showed potential for clinical use [153].

The fluorescence polarization assay (FPA) uses a tracer (the target antigen or part of it) with a fluorescent molecule bound to it, to detect antibody in serum [154]. It has recently been tested in elk and red deer [155]. Though the OIE previously classified this as a test of scientific value only, due to costs and logistic demands [43], the development of a portable fluorescence polarization analyzer facilitates testing performed in the field and the test procedure has now become simple and rapid [155]. 
Western blotting is an established technique and uses gel electrophoresis to detect proteins. When it was compared with the Brock ELISA, a serological test for diagnosis of BTB in badgers, it was less sensitive than the ELISA ( $68 \%$ versus $57 \%$, same group of badgers, no specificity was measured) [156]. Western blotting was also used in other studies as a proof of principle method to show that real antibodies were measured with MAPIA / ELISA [147] or the lateral-flow immunochromatographic test [129].

Other BTB diagnostic methods, which are more laboratory based methods, include the lymphocyte transformation assay $[69,71]$ and the measurement of production of nitric oxide (NO) or Tumor Necrosis Factor (TNF) a to measure macrophage activity [157]. The production of NO in response to antigen specific stimulation of PBMC of $M$. bovis infected white-tailed deer gave promising results [158], but additional studies to measure NO responses of more species, or follow-up studies, are lacking.

New non-immunological methods are also being developed, including a volatile compound-sensing system, that was tested for badgers and cattle. This 'electronic nose' used serum samples and was able to discriminate experimentally infected animals from controls as early as 3 weeks after infection with M. bovis [159]. A similar serological technology, "selected ion flow tube mass spectrometry", was combined with multivariate data analysis for the diagnosis of $M$. bovis in badgers, which showed $88 \%$ true positives, but only $62 \%$ true negatives [160]. 


\section{Diagnostic approaches to improve assay fitness for purpose}

Currently, no single test is applicable for all species and/or test purposes. Part of the BTB test requirements may still be covered by applying various diagnostic approaches to the available, imperfect diagnostic methods. Several of these approaches that could improve the fitness of diagnostic assays are discussed here and should be considered in particular management situations.

\subsection{Sensitivity (Se) versus specificity (Sp)}

A balance exists between the Se of a test, i.e. the probability of correctly identifying an infected animal, and the $\mathrm{Sp}$, i.e. the probability of correctly identifying a non-infected animal [161]. This balance can be shifted by adjusting the cut-off value of the diagnostic assay to optimise the test outcome for the desired test characteristics. Adjusting the balance with the use of two different interpretation schemes for infected versus uninfected populations was shown to add value to the use of both the tuberculin skin test in domestic cattle [162] and the IFN-y assay in buffalo [39].

Herd-level test characteristics may differ from individual-level test characteristics, because the unit of inference is different [163]. For example, in general detection of $M$. bovis infection on herd level is deemed more easy, since in theory only one animal needs to be diagnosed with $M$. bovis infection to classify the entire herd positive for BTB, a method that is used in farmed deer in Sweden [51]. Therefore, a test with imperfect Se could give 
reasonable results when used on herd/population level [163]. Additional methods exist to compensate for a lack in Se, like increasing the sample number in surveillance and monitoring exercises. Depending on definitions of positive results, the use of defined mycobacterial antigens in the IFN-Y assay, for example ESAT6 and CFP10, additional to PPDA and PPDB, may be used to increase Sp (i.e. an animal is regarded positive when both are positive) or Se (i.e. an animal is regarded positive when either one is positive) $[105,133,164]$

\subsection{Combination of tests}

Combining different testing methods is another strategy to improve the Se or $\mathrm{Sp}$, though at the expense of higher costs. Parallel testing of multiple tests for individual diagnosis results in maximal Se, at the cost of lower Sp, which can be used when disease prevalence is high. On the other hand, to increase Sp serial testing can be used in (individual animals in) herds where negative results are expected, even though it will lower the Se. Another strategy is to use an inexpensive screening test with a high $\mathrm{Se}$ and moderate $\mathrm{Sp}$, with subsequent retesting of positive animals with a more expensive ancillary test which is both sensitive and specific.

How the Se and Sp are influenced by the parallel or serial combination of tests, also depends on the conditional dependence between the tests, i.e. if they measure the same biological processes $[163,165]$. With the combination of $\mathrm{CMI}$ and serology-based tests, a larger window of the immune response can be covered, resulting in the detection of a higher percentage of infected 
animals in cattle [166], non-human primates [128] and fallow deer [167]. However, such combinations improved the Se of detection only marginally in badgers [106] and red deer [149]. Combinations of two CMI based tests or two serology-based assays have also been tested. Using PRIMAGAM (primate IFN- $\mathrm{y}$ assay) and the skin test in parallel increased the overall Se of screening to $100 \%$ [100]. The parallel use of lateral-flow immunochromatographic test and MAPIA in wild meerkats produced estimates of Se and Sp that were considered high enough to be useful for BTB diagnosis, where the use of either test alone was not [81].

Serial testing, can influence the outcome of the second test: performing a serologic assay 2-8 weeks after tuberculin testing of infected cervids resulted in improved results due to an anamnestic rise in antibodies specific for $M$. bovis $[129,147]$. It may also influence the IFN-Y assay, though literature is contrasting in this field, as reviewed in [115]. Serial testing of (free-ranging) wildlife is difficult, since it necessitates multiple captures.

\subsection{Targeted animal sampling}

Specific species can be targeted for sampling to detect $M$. bovis infection, for example for surveillance or monitoring. These species could be scavenger species like coyotes, that could serve as sentinel species for $M$. bovis presence [168]. Also, animals that are highly susceptible for $M$. bovis (bovine/deer species) could be targets. Targeted sampling may also involve only sampling a specific (fraction of a) population that is more likely to be infected, increasing the herd Se of diagnostic methods, as the prevalence of 
that target population is higher [163]. An example of this type of targeted sampling is the culture of samples from only those animals during routine cropping, e.g. hunting, that show lesions during necropsies.

\section{Considerations for future test development and applications}

Even with the application of the various approaches to the available diagnostic assays, there are still numerous situations where assays do not meet the requirements for BTB management, especially when testing individual animals or small populations [9] testing for BTB-free certification [64]. New and modified diagnostic methods continue to be developed and validated, a process that could be aided by the following considerations.

\subsection{Multi-species tests}

Multi-species tests could offer a solution to testing those wildlife species for which development of a species specific assay would not be economically viable, e.g. many captive wildlife species in zoological collections. Multispecies wildlife tests can potentially arise from existing assays for domestic animals $[39,169]$ or humans [99]. However, these tests cannot be assumed to be equally sensitive or specific in their wildlife counterparts $[36,48]$ and test validation is crucial for each (group of) species and sample type [67]

Direct tests like culture, PCR or the direct immunofluorescense assay can be used as multi-species test and though test characteristics per se are similar for most species [36], the applicability may differ across species, as the 
bacterial load in lesions and the extent of lesions may differ between species $[22,73,170]$ and shedding of mycobacteria is irregular $[82,83]$.

Indirect immunological methods that use cross-reactive reagents have also been used as multi-species test, though with varying success [36]. For example, the Bovigam IFN-y assay for cattle, can be used in similar species like buffaloes [39], and the Primagam IFN- $\mathrm{Y}$ assay in various non-human primates [33], though validation for each species remains essential as was shown for cynomolgus macaques [100], for which lower test sensitivities were found. Serological assays like ELISAs [171] or MAPIA [127] also offer multispecies potential, for example by using protein A or $\mathrm{G}$ as secondary antibody, binding immunoglobulins across species [172]. The lateral-flow immunochromatographic tests have already shown to be useful across different species, though for some species the composition of the different antigens that are being used, should be optimized [140].

\subsection{Validation challenges}

After initial assay development, including optimization and calibration of the assay to standard reagents, the first stage of assay validation constitutes the determination of the analytical $\mathrm{Se}$ and $\mathrm{Sp}$ and of the test repeatability. This involves a small panel of coded control samples and should preferably be performed in multiple laboratories. The second stage involves assessment of the diagnostic performance, measured against a gold standard test, and uses field samples [173]. Practically, acquiring the OIE recommended numbers of known positive and negative controls for validation $[173,174]$ will be difficult 
for many wildlife species [48], and initially the necessary sample size may not be achievable. However, over time, collecting data should result in large enough sample numbers to estimate diagnostic Se and Sp. Collection of data may be aided by following standard protocols for testing, e.g. the Standard for Reporting of Diagnostic Accuracy (STARD), which can help improve quality of the methods $[44,175]$. However, challenges like a validated ante mortem diagnosis in rare species/zoo animals still exist and may not be solved soon.

Estimates of diagnostic Se and Sp should be made in populations that are as close as possible to the population in which the diagnostic tests will be used, as was stipulated by the Office International des Epizooties [37]. Test characteristics and the outcome of the study are influenced by the type of study (natural versus experimental infection, different gold standards), as well as confounding factors such as co-infection need to be taken into account when possible [149] .

\subsection{Gold standard versus latent class models}

The gold standard diagnostic method for tuberculosis is the mycobacterial culture. However, this direct assay has several disadvantages, like long processing time and variable sensitivity across species, and it is therefore an imperfect gold standard. If the gold standard test itself does not have $100 \%$ Se and $100 \%$ Sp, errors will arise in defining Se and Sp of new diagnostic assays [44]. The sensitivities of new diagnostic tests should therefore rather be described as 'relative sensitivities', since they are estimated by comparison to the imperfect gold standard of culture. 
Because an ideal gold standard is not available, new methods have been developed to avoid the need of the gold standard for the validation of diagnostic assays. A very useful method is the use of latent class models. These can use either frequentist (maximum likelihood estimation) or Bayesian modeling strategies to estimate the operating characteristics of two or more diagnostic tests where true disease status is not known [176-178]. Studies using this method are increasingly published, for cattle $[126,179]$ as well as as for wildlife [81]. A disadvantage of Bayesian modeling is the use of prior assumptions, including independence of different tests, which complicates analyses of diagnostic tests that are based on the same stage of the immune response (i.e. the tuberculin skin test and the IFN-y assay).

\section{Conclusion}

This review investigated the available (ante mortem) diagnostic assays for detection of $M$. bovis infection. CMI based tests like the IFN- $\gamma$ assay still form the major basis of (B)TB testing in cattle and humans and are still regarded as the earliest detectors of positive animals, but their use in wildlife species is complicated by their species-specific set-up. In general, they offer reasonably high test sensitivities in the wildlife species they have been developed for (table 1). New specific immunodominant antigens offer potential to increase specificity and avoid cross-reactions with other mycobacteria and BCG vaccination. Serological tests have greatly improved their sensitivity, though still for some species the low sensitivity and the need for species specific antibodies remains problematic, as shown in table 1. Their ease of use as 
animals-side tests may offer great potential for BTB detection in (free-ranging) wildlife.

Diagnostic testing of wildlife species for $M$. bovis can be necessary for various purposes, from surveillance on population level, to certification of BTB-free status for individual animals or the confirmatory diagnosis in suspected cases of the disease. Given the complex background of pathogenesis and host immune responses to $M$. bovis infection, it is not likely that in the near future a single assay with perfect diagnostic performance will become available for BTB management. Therefore, a test or combination of tests and diagnostic approaches need to be chosen that are most "fit for purpose". The fit for purpose principal includes the crucial balance between sensitivity and specificity and specification of the species, as well as availability, ease of use, logistical demands, reproducibility and the costs of the diagnostic assays [149]. A cost-effective test therefore does not generally mean the cheapest test [93] and fitness may differ between geographical locations and between developed and developing countries [2]. Important shortcomings remain present, and for some species or testing purposes, it is unlikely that a good diagnostic assay will be available soon.

\section{Acknowledgements}

The work of MM was supported by the Netherlands Organisation for Scientific

Research (NWO/ZonMw grant 918.56.620) and the Prins Bernhard Cultuurfonds on behalf of the Niemans-Schootemeijer Fonds. 


\section{Conflict of interest}

None

\section{References}

[1] Donnelly CA, Woodroffe R, Cox DR, Bourne J, Gettinby G, Le Fevre AM, et al. Impact of localized badger culling on tuberculosis incidence in British cattle. Nature 2003;426(6968):834-7.

[2] Michel AL, Muller B, van Helden PD. Mycobacterium bovis at the animalhuman interface: a problem, or not? Vet.Microbiol. 2010;140(3-4):371-81.

[3] Mishra A, Singhal A, Chauhan DS, Katoch VM, Srivastava K, Thakral SS, et al. Direct detection and identification of Mycobacterium tuberculosis and Mycobacterium bovis in bovine samples by a novel nested PCR assay: correlation with conventional techniques. J.Clin.Microbiol. 2005;43(11):56708.

[4] Michel AL, Bengis RG, Keet DF, Hofmeyr M, Klerk LM, Cross PC, et al. Wildlife tuberculosis in South African conservation areas: implications and challenges. Vet.Microbiol. 2006;112(2-4):91-100.

[5] O'Brien DJ, Schmitt SM, Rudolph BA, Nugent G. Recent advances in the management of bovine tuberculosis in free-ranging wildlife. Vet.Microbiol. 2011;151(1-2):23-33.

[6] Amanfu W. The situation of tuberculosis and tuberculosis control in animals of economic interest. Tuberculosis (Edinb) 2006;86(3-4):330-5.

[7] European Food Safety Authority, European Centre for Disease Prevention and Control. The European Union Summary Report on Trends and Sources of Zoonoses, Zoonotic Agents and Food-Borne Outreaks in 2009. EFSA Journal 2011;9(3):1-378.

[8] de Lisle GW, Bengis RG, Schmitt SM, O'Brien DJ. Tuberculosis in freeranging wildlife: detection, diagnosis and management. Rev.Sci.Tech. 2002;21(2):317-34.

[9] Lécu A, Ball R. Mycobacterial infections in zoo animals: relevance, diagnosis and management ${ }^{*}$. International Zoo Yearbook 2011;45(1):183-202.

[10] Nation PN, Fanning EA, Hopf HB, Church TL. Observations on animal and human health during the outbreak of Mycobacterium bovis in game farm wapiti in Alberta. Can.Vet.J. 1999;40(2):113-7. 
[11] Delahay RJ, Cheeseman CL, Clifton-Hadley RS. Wildlife disease reservoirs: the epidemiology of Mycobacterium bovis infection in the European badger (Meles meles) and other British mammals. Tuberculosis (Edinb) 2001;81(1-2):43-9.

[12] Wilson GJ, Carter SP, Delahay RJ. Advances and prospects for management of TB transmission between badgers and cattle. Vet.Microbiol. 2011;151(1-2):43-50.

[13] Cross PC, Heisey DM, Bowers JA, Hay CT, Wolhuter J, Buss P, et al. Disease, predation and demography: assessing the impacts of bovine tuberculosis on African buffalo by monitoring at individual and population levels. J.Appl.Ecol. 2009;46(2):467-75.

[14] Nugent G. Maintenance, spillover and spillback transmission of bovine tuberculosis in multi-host wildlife complexes: a New Zealand case study. Vet.Microbiol. 2011;151(1-2):34-42.

[15] O'Brien DJ, Schmitt SM, Fitzgerald SD, Berry DE, Hickling GJ. Managing the wildlife reservoir of Mycobacterium bovis: the Michigan, USA, experience. Vet.Microbiol. 2006;112(2-4):313-23.

[16] Gortazar C, Vicente J, Boadella M, Ballesteros C, Galindo RC, Garrido J, et al. Progress in the control of bovine tuberculosis in Spanish wildlife. Vet.Microbiol. 2011;151(1-2):170-8.

[17] Gamma interferon enzyme immunoassays and their use in the investigation of tuberculosis in a western lowland gorilla. Proceedings of the wildlife disease association australasian section annual conference 2003; 2003.

[18] Briones V, de Juan L, Sanchez C, Vela Al, Galka M, Montero, et al. Bovine tuberculosis and the endangered Iberian lynx. Emerg.Infect.Dis. 2000;6(2):189-91.

[19] Espie IW, Hlokwe TM, Gey van Pittius NC, Lane E, Tordiffe AS, Michel $A L$, et al. Pulmonary infection due to Mycobacterium bovis in a black rhinoceros (Diceros bicornis minor) in South Africa. J.Wildl.Dis. 2009;45(4):1187-93.

[20] Dalovisio JR, Stetter M, Mikota-Wells S. Rhinoceros' Rhinorrhea: Cause of an Outbreak of Infection Due to Airborne Mycobacterium bovis in Zookeepers. Clinical Infectious Diseases 1992;15(4):598-600.

[21] Keet DF, Kriek NP, Penrith ML, Michel A, Huchzermeyer H. Tuberculosis in buffaloes (Syncerus caffer) in the Kruger National Park: spread of the disease to other species. Onderstepoort J.Vet.Res. 1996;63(3):239-44.

[22] Keet DF, Michel AL, Bengis RG, Becker P, van Dyk DS, van Vuuren M, et al. Intradermal tuberculin testing of wild African lions (Panthera leo) naturally 
exposed to infection with Mycobacterium bovis. Vet.Microbiol. 2010;144(34):384-91.

[23] Corner LA. The role of wild animal populations in the epidemiology of tuberculosis in domestic animals: how to assess the risk. Vet.Microbiol. 2006;112(2-4):303-12.

[24] Fanning A, Edwards S. Mycobacterium bovis infection in human beings in contact with elk (Cervus elaphus) in Alberta, Canada. Lancet 1991;338(8777):1253-5.

[25] Liss GM, Wong L, Kittle DC, Simor A, Naus M, Martiquet P, et al. Occupational exposure to Mycobacterium bovis infection in deer and elk in Ontario. Can.J.Public Health 1994;85(5):326-9.

[26] Hlavsa MC, Moonan PK, Cowan LS, Navin TR, Kammerer JS, Morlock GP, et al. Human tuberculosis due to Mycobacterium bovis in the United States, 1995-2005. Clin.Infect.Dis. 2008;47(2):168-75.

[27] Berg S, Firdessa R, Habtamu M, Gadisa E, Mengistu A, Yamuah L, et al. The burden of mycobacterial disease in ethiopian cattle: implications for public health. PLoS One 2009;4(4):e5068.

[28] Michel AL, Huchzermeyer HF. The zoonotic importance of Mycobacterium tuberculosis: transmission from human to monkey. J.S.Afr.Vet.Assoc. 1998;69(2):64-5.

[29] Michel AL, Venter L, Espie IW, Coetzee ML. Mycobacterium tuberculosis infections in eight species at the National Zoological Gardens of South Africa, 1991-2001. J.Zoo Wildl.Med. 2003;34(4):364-70.

[30] Lewerin SS, Olsson SL, Eld K, Roken B, Ghebremichael S, Koivula T, et al. Outbreak of Mycobacterium tuberculosis infection among captive Asian elephants in a Swedish zoo. Vet.Rec. 2005;156(6):171-5.

[31] Oh P, Granich R, Scott J, Sun B, Joseph M, Stringfield C, et al. Human exposure following Mycobacterium tuberculosis infection of multiple animal species in a Metropolitan Zoo. Emerg.Infect.Dis. 2002;8(11):1290-3.

[32] Montali RJ, Mikota SK, Cheng LI. Mycobacterium tuberculosis in zoo and wildlife species. Rev.Sci.Tech. 2001;20(1):291-303.

[33] Vervenne RA, Jones SL, van Soolingen D, van der Laan T, Andersen $P$, Heidt PJ, et al. TB diagnosis in non-human primates: comparison of two interferon-gamma assays and the skin test for identification of Mycobacterium tuberculosis infection. Vet.Immunol.Immunopathol. 2004;100(1-2):61-71.

[34] Angkawanish T, Wajjwalku W, Sirimalaisuwan A, Mahasawangkul S, Kaewsakhorn T, Boonsri K, et al. Mycobacterium tuberculosis infection of 
domesticated Asian elephants, Thailand. Emerg.Infect.Dis. 2010;16(12):194951.

[35] Alexander KA, Pleydell E, Williams MC, Lane EP, Nyange JF, Michel AL. Mycobacterium tuberculosis: an emerging disease of free-ranging wildlife. Emerg.Infect.Dis. 2002;8(6):598-601.

[36] Bengis RG, Kock RA, Fischer J. Infectious animal diseases: the wildlife/livestock interface. Rev.Sci.Tech. 2002;21(1):53-65.

[37] Cousins DV, Florisson N. A review of tests available for use in the diagnosis of tuberculosis in non-bovine species. Rev.Sci.Tech. 2005;24(3):1039-59.

[38] Chambers MA. Review of the Diagnosis and Study of Tuberculosis in Non-Bovine Wildlife Species Using Immunological Methods. Transboundary and Emerging Diseases 2009;56(6-7):215-27.

[39] Michel AL, Cooper D, Jooste J, de Klerk LM, Jolles A. Approaches towards optimising the gamma interferon assay for diagnosing Mycobacterium bovis infection in African buffalo (Syncerus caffer). Prev.Vet.Med. 2011;98(23):142-51.

[40] Diagnosis of bovine tuberculosis in lions: present and future. 30th World Veterinary Congress; 2011.

[41] Bovine tuberculosis:diagnostic challenges in wildlife and livestock. 30th World Veterinary Congress; 2011.

[42] Wright P, Edwards S, Diallo A, Jacobson R. Development of a framework for international certification by OIE of diagnostic tests validated as fit for purpose. Dev.Biol.(Basel) 2006;126:43,51; discussion 324-5.

[43] Anonymous. Chapter 2.4.7. Bovine tuberculosis. Manual of diagnostic tests and vaccines for terrestrial animals: Office International des Epizooties (OIE); 2009.

[44] TDR Diagnostics Evaluation Expert Panel, Banoo S, Bell D, Bossuyt P, Herring A, Mabey D, et al. Evaluation of diagnostic tests for infectious diseases: general principles. Nat.Rev.Microbiol. 2010;8(12 Suppl):S17-29.

[45] Anonymous. Chapter 1.4. Animal health surveillance. Terrestrial animal health code: Office International des Epizooties (OIE); 2011.

[46] APHIS (Animal and Plant Health Inspection Service). Guidelines for Surveillance of Bovine Tuberculosis in Wildlife. 2011;.

[47] Schmitt S, Fitzgerald S, Cooley T, Bruning-Fann C, Sullivan L, Berry D, et al. Bovine tuberculosis in free-ranging white-tailed deer from Michigan. Journal of Wildlife Diseases 1997;33(4):749-58. 
[48] Artois M, Bengis RG, Delahay RJ, Duchêne M, Duff JP, Ferroglio E, et al. Chapter 10: Wildlife Diasease Surveillance and Monitoring. In: Delahay RJ, Smith GC, Hutchings MR, editors. Management of Disease in Wild MammalsJapan: Springer; 2009, p. 187-213.

[49] Vicente J, Hofle U, Garrido JM, Fernandez-de-Mera IG, Acevedo P, Juste $R$, et al. Risk factors associated with the prevalence of tuberculosis-like lesions in fenced wild boar and red deer in south central Spain. Vet.Res. 2007;38(3):451-64.

[50] Ekdahl MO, Smith BL, Money DFL. Letters to the editor. N.Z.Vet.J. 1970;18(3):44-5.

[51] Wahlström H, Englund L. Adopting control principles in a novel setting. Vet.Microbiol. 2006;112(2-4):265-71.

[52] Cleaveland S, Mlengeya T, Kazwala RR, Michel A, Kaare MT, Jones SL, et al. Tuberculosis in Tanzanian wildlife. J.Wildl.Dis. 2005;41(2):446-53.

[53] Buddle BM, Wedlock DN, Denis M, Vordermeier HM, Hewinson RG. Update on vaccination of cattle and wildlife populations against tuberculosis. Vet.Microbiol. 2011;151(1-2):14-22.

[54] Schmidbauer S, Wohlsein P, Kirpal G, Beineke A, Müller G, Müller H, et al. Outbreak of Mycobacterium bovis infection in a wild animal park. Veterinary Record 2007;161(9):304-7.

[55] Michalak K, Austin C, Diesel S, Bacon MJ, Zimmerman P, Maslow JN. Mycobacterium tuberculosis infection as a zoonotic disease: transmission between humans and elephants. Emerg.Infect.Dis. 1998;4(2):283-7.

[56] Bush M, Montali RJ, Phillips Jr. LG, Holobaugh PA. Bovine tuberculosis in a Bactrian camel herd: clinical, therapeutic, and pathologic findings. Journal of Zoo and Wildlife Medicine 1990;21(2):171-179.

[57] Mikota SK, Peddie L, Peddie J, Isaza R, Dunker F, West G, et al. Epidemiology and diagnosis of Mycobacterium tuberculosis in captive Asian elephants (Elephas maximus). J.Zoo Wildl.Med. 2001;32(1):1-16.

[58] Lerche NW, Yee JL, Capuano SV, Flynn JL. New approaches to tuberculosis surveillance in nonhuman primates. ILAR J. 2008;49(2):170-8.

[59] Chambers MA, Crawshaw T, Waterhouse S, Delahay R, Hewinson RG, Lyashchenko KP. Validation of the BrockTB stat-pak assay for detection of tuberculosis in Eurasian badgers (Meles meles) and influence of disease severity on diagnostic accuracy. J.Clin.Microbiol. 2008;46(4):1498-500.

[60] Michel AL, Simões M. Comparative field evaluation of two rapid immunochromatographic tests for the diagnosis of bovine tuberculosis in 
African buffaloes (Syncerus caffer). Vet.Immunol.Immunopathol. 2009;127(12):186-9.

[61] Van der Merwe M, Michel AL. An investigation of the effects of secondary processing on Mycobacterium spp. in naturally infected game meat and organs. J.S.Afr.Vet.Assoc. 2010;81(3):166-9.

[62] de la Rua-Domenech R. Human Mycobacterium bovis infection in the United Kingdom: Incidence, risks, control measures and review of the zoonotic aspects of bovine tuberculosis. Tuberculosis 2006;86(2):77-109.

[63] Woodford MH editor. Quarantine and Health Screening Protocols for Wildlife prior to Translocation and Release into the Wild. : Published jointly by the IUCN Species Survival Commission's Veterinary Specialist Group, Gland, Switzerland, The OIE, Paris, France, Care for the Wild, U.K., and the European Association of Zoo and Wildlife Veterinarians, Switzerland; 2000.

[64] Osterhaus A, Algers B, Müller-Graf C, Guemene D, Morton DB, Pfeiffer DU, et al. Scientific Opinion of the Panel on Animal Health and Animal Welfare on a request from the European Commission on "Tuberculosis testing in deer". The EFSA Journal 2008;645:1-34.

[65] Anonymous. http://www.daff.gov.zal: Disease risk management directive for buffalo (Syncerus caffer) in South Africa. Available at: http://www.daff.gov.zal. Accessed March 4, 2012.

[66] Michel AL, Bengis RG. The African buffalo: A villain for inter-species spread of infectious diseases in southern Africa. Onderstepoort Journal of Veterinary Research 2012;79(2).

[67] Santos N, Geraldes M, Afonso A, Almeida V, Correia-Neves M. Diagnosis of Tuberculosis in the Wild Boar (Sus scrofa): A Comparison of Methods Applicable to Hunter-Harvested Animals. PLoS ONE 2010;5(9):e12663.

[68] Jolles AE, Ezenwa VO, Etienne RS, Turner WC, Olff H. Interactions between macroparasites and microparasites drive infection patterns in freeranging African buffalo. Ecology 2008;89(8):2239-50.

[69] Lesellier S, Corner L, Costello E, Sleeman P, Lyashchenko K, Greenwald $\mathrm{R}$, et al. Antigen specific immunological responses of badgers (Meles meles) experimentally infected with Mycobacterium bovis.

Vet.Immunol.Immunopathol. 2008;122(1-2):35-45.

[70] Schrenzel MD. Molecular Epidemiology of Mycobacteriosis in Wildlife and Pet Animals. Veterinary Clinics of North America - Exotic Animal Practice 2012;15(1):1-23.

[71] Harrington NP, Surujballi OP, Waters WR, Prescott JF. Development and evaluation of a real-time reverse transcription-PCR assay for quantification of 
gamma interferon mRNA to diagnose tuberculosis in multiple animal species. Clin.Vaccine Immunol. 2007;14(12):1563-71.

[72] Miller J, Jenny A, Rhyan J, Saari D, Suarez D. Detection of Mycobacterium Bovis in Formalin-Fixed, Paraffin-Embedded Tissues of Cattle and Elk by PCR Amplification of an IS6110 Sequence Specific for Mycobacterium Tuberculosis Complex Organisms. Journal of Veterinary Diagnostic Investigation 1997;9(3):244-9.

[73] Fitzgerald SD, Kaneene JB, Butler KL, Clarke KR, Fierke JS, Schmitt SM, et al. Comparison of Postmortem Techniques for the Detection of Mycobacterium Bovis in White-Tailed Deer (Odocoileus Virginianus). Journal of Veterinary Diagnostic Investigation 2000;12(4):322-7.

[74] De Vos V, Bengis RG, Kriek NPJ, Michel A, Keet DF, Raath JP, et al. The epidemiology of tuberculosis in free-ranging African buffalo (Syncerus caffer) in the Kruger national park, South Africa. Onderstepoort J.Vet.Res. 2001;68(2):119-30.

[75] O'Brien DJ, Schmitt SM, Berry DE, Fitzgerald SD, Vanneste JR, Lyon TJ, et al. Estimating the true prevalence of Mycobacterium bovis in hunterharvested white-tailed deer in Michigan Journal of Wildlife Diseases 2004;40(1):42-52.

[76] Rohonczy EB, Balachandran AV, Dukes TW, Payeur JB, Rhyan JC, Saari $\mathrm{DA}$, et al. A comparison of gross pathology, histopathology, and mycobacterial culture for the diagnosis of tuberculosis in elk (Cervus elaphus).

Can.J.Vet.Res. 1996;60(2):108-14.

[77] Corner LA, Murphy D, Gormley E. Mycobacterium bovis infection in the Eurasian badger (Meles meles): the disease, pathogenesis, epidemiology and control. J.Comp.Pathol. 2011;144(1):1-24.

[78] O'Brien DJ, Schmitt SM, Berry DE, Fitzgerald SD, Lyon TJ, Vanneste JR, et al. Estimating the true prevalence of Mycobacterium bovis in free-ranging elk in Michigan. J.Wildl.Dis. 2008;44(4):802-10.

[79] Mohamed M, Moussa IM, Mohamed KF, Samir A, Nasr EA, Ashgan MH, et al. BACTEC MGIT $960{ }^{\text {TM }}$ system for screening of Mycobacterium tuberculosis complex among cattle. African Journal of Biotechnology 2011;10(63):13919-13923.

[80] Michel AL, Coetzee ML, Keet DF, Maré L, Warren R, Cooper D, et al. Molecular epidemiology of Mycobacterium bovis isolates from free-ranging wildlife in South African game reserves. Vet.Microbiol. 2009;133(4):335-43.

[81] Drewe JA, Dean GS, Michel AL, Lyashchenko KP, Greenwald R, Pearce GP. Accuracy of three diagnostic tests for determining Mycobacterium bovis infection status in live-sampled wild meerkats (Suricata suricatta).

J.Vet.Diagn.Invest. 2009;21(1):31-9. 
[82] Neill SD, Hanna J, O'Brien JJ, McCracken RM. Excretion of Mycobacterium bovis by experimentally infected cattle. Vet.Rec. 1988;123(13):340-3.

[83] Clifton-Hadley RS, Wilesmith JW, Stuart FA. Mycobacterium bovis in the European Badger (Meles meles): Epidemiological Findings in Tuberculous Badgers from a Naturally Infected Population. Epidemiol.Infect. 1993;111(1):9-19.

[84] van Helden PD, Gey van Pittius NC, Warren RM, Michel A, Hlokwe T, Morar D, et al. Pulmonary infection due to Mycobacterium goodii in a spotted hyena (Crocuta crocuta) from South Africa. J.Wildl.Dis. 2008;44(1):151-4.

[85] Harmsen D, Dostal S, Roth A, Niemann S, Rothganger J, Sammeth M, et al. RIDOM: comprehensive and public sequence database for identification of Mycobacterium species. BMC Infect.Dis. 2003;3:26.

[86] Jackson R, Cooke MM, Coleman JD, Morris RS, de Lisle GW, Yates GF. Naturally occurring tuberculosis caused by Mycobacterium bovis in brushtail possums (Trichosurus vulpecula): III. Routes of infection and excretion. N.Z.Vet.J. 1995;43(7):322-7.

[87] Gortazar C, Torres MJ, Vicente J, Acevedo P, Reglero M, de la Fuente J, et al. Bovine tuberculosis in Donana Biosphere Reserve: the role of wild ungulates as disease reservoirs in the last Iberian lynx strongholds. PLoS One 2008;3(7):e2776.

[88] Pollock JM, Rodgers JD, Welsh MD, McNair J. Pathogenesis of bovine tuberculosis: the role of experimental models of infection. Vet.Microbiol. 2006;112(2-4):141-50.

[89] Pollock JM, McNair J, Welsh MD, Girvin RM, Kennedy HE, Mackie DP, et al. Immune responses in bovine tuberculosis. Tuberculosis (Edinb) 2001;81(12):103-7.

[90] Welsh MD, Cunningham RT, Corbett DM, Girvin RM, McNair J, Skuce $\mathrm{RA}$, et al. Influence of pathological progression on the balance between cellular and humoral immune responses in bovine tuberculosis. Immunology 2005;114(1):101-11.

[91] Pollock JM, Neill SD. Mycobacterium bovis infection and tuberculosis in cattle. Vet.J. 2002;163(2):115-27.

[92] de la Rua-Domenech R, Goodchild AT, Vordermeier HM, Hewinson RG, Christiansen $\mathrm{KH}$, Clifton-Hadley RS. Ante mortem diagnosis of tuberculosis in cattle: a review of the tuberculin tests, gamma-interferon assay and other ancillary diagnostic techniques. Res.Vet.Sci. 2006;81(2):190-210.

[93] Schiller I, Oesch B, Vordermeier HM, Palmer MV, Harris BN, Orloski KA, et al. Bovine tuberculosis: a review of current and emerging diagnostic 
techniques in view of their relevance for disease control and eradication. Transbound Emerg.Dis. 2010;57(4):205-20.

[94] Monaghan ML, Doherty ML, Collins JD, Kazda JF, Quinn PJ. The tuberculin test. Vet.Microbiol. 1994;40(1-2):111-24.

[95] Palmer MV, Whipple DL, Payeur JB, Bolin CA. Use of the intradermal tuberculin test in a herd of captive elk (Cervus elaphus nelsoni) naturally infected with Mycobacterium bovis. J.Vet.Diagn.Invest. 2011;23(2):363-6.

[96] Corrin KC, Carter CE, Kissling RC, de Lisle GW. An evaluation of the comparative tuberculin skin test for detecting tuberculosis in farmed deer. N.Z.Vet.J. 1993;41(1):12-20.

[97] Duncan AE, Lyashchenko K, Greenwald R, Miller M, Ball R. Application of Elephant TB STAT-PAK assay and MAPIA (multi-antigen print immunoassay) for detection of tuberculosis and monitoring of treatment in black rhinoceros (Diceros bicornis). J.Zoo Wildl.Med. 2009;40(4):781-5.

[98] Wood PR, Corner LA, Plackett P. Development of a simple, rapid in vitro cellular assay for bovine tuberculosis based on the production of gamma interferon. Res.Vet.Sci. 1990;49(1):46-9.

[99] Parsons SD, Cooper D, McCall AJ, McCall WA, Streicher EM, le Maitre NC, et al. Modification of the QuantiFERON-TB Gold (In-Tube) assay for the diagnosis of Mycobacterium bovis infection in African buffaloes (Syncerus caffer). Vet.Immunol.Immunopathol. 2011;142(1-2):113-8.

[100] Garcia MA, Yee J, Bouley DM, Moorhead R, Lerche NW. Diagnosis of tuberculosis in macaques, using whole-blood in vitro interferon-gamma (PRIMAGAM) testing. Comp.Med. 2004;54(1):86-92.

[101] Lesellier S, Palmer S, Dalley DJ, Dave D, Johnson L, Hewinson RG, et al. The safety and immunogenicity of Bacillus Calmette-Guerin (BCG) vaccine in European badgers (Meles meles). Vet.Immunol.Immunopathol. 2006;112(12):24-37.

[102] Wang JY, Chou CH, Lee LN, Hsu HL, Jan IS, Hsueh PR, et al. Diagnosis of tuberculosis by an enzyme-linked immunospot assay for interferon-gamma. Emerg.Infect.Dis. 2007;13(4):553-8.

[103] Lin PL, Yee J, Klein E, Lerche NW. Immunological concepts in tuberculosis diagnostics for non-human primates: a review. J.Med.Primatol. 2008;37 Suppl 1:44-51.

[104] Doherty TM, Demissie A, Menzies D, Andersen P, Rook G, Zumla A. Effect of sample handling on analysis of cytokine responses to Mycobacterium tuberculosis in clinical samples using ELISA, ELISPOT and quantitative PCR. J.Immunol.Methods 2005;298(1-2):129-41. 
[105] Andersen P, Munk M, Pollock J, Doherty T. Specific immune-based diagnosis of tuberculosis. The Lancet, 2000;356(9235):1099-104.

[106] Dalley D, Dave D, Lesellier S, Palmer S, Crawshaw T, Hewinson RG, et al. Development and evaluation of a gamma-interferon assay for tuberculosis in badgers (Meles meles). Tuberculosis (Edinb) 2008;88(3):235-43.

[107] Aranaz A, De Juan L, Bezos J, Alvarez J, Romero B, Lozano F, et al. Assessment of diagnostic tools for eradication of bovine tuberculosis in cattle co-infected with Mycobacterium bovis and M. avium subsp. paratuberculosis. Vet.Res. 2006;37(4):593-606.

[108] Barry C, Corbett D, Bakker D, Andersen P, McNair J, Strain S. The Effect of Mycobacterium avium Complex Infections on Routine Mycobacterium bovis Diagnostic Tests. Vet.Med.Int. 2011;2011:145092.

[109] Cockle PJ, Gordon SV, Hewinson RG, Vordermeier HM. Field evaluation of a novel differential diagnostic reagent for detection of Mycobacterium bovis in cattle. Clin.Vaccine Immunol. 2006;13(10):1119-24.

[110] Sidders B, Pirson C, Hogarth PJ, Hewinson RG, Stoker NG, Vordermeier HM, et al. Screening of highly expressed mycobacterial genes identifies Rv3615c as a useful differential diagnostic antigen for the Mycobacterium tuberculosis complex. Infect.Immun. 2008;76(9):3932-9.

[111] Jones GJ, Hewinson RG, Vordermeier HM. Screening of predicted secreted antigens from Mycobacterium bovis identifies potential novel differential diagnostic reagents. Clin.Vaccine Immunol. 2010;17(9):1344-8.

[112] Dinnes J, Deeks J, Kunst H, Gibson A, Cummins E, Waugh N, et al. A systematic review of rapid diagnostic tests for the detection of tuberculosis infection. Health Technol.Assess. 2007;11(3).

[113] Vordermeier HM, Whelan A, Cockle PJ, Farrant L, Palmer N, Hewinson RG. Use of synthetic peptides derived from the antigens ESAT- 6 and CFP-10 for differential diagnosis of bovine tuberculosis in cattle.

Clin.Diagn.Lab.Immunol. 2001;8(3):571-8.

[114] Andersen P, Doherty TM, Pai M, Weldingh K. The prognosis of latent tuberculosis: can disease be predicted? Trends in Molecular Medicine, 2007;13(5):175-82.

[115] Gormley E, Doyle MB, Fitzsimons T, McGill K, Collins JD. Diagnosis of Mycobacterium bovis infection in cattle by use of the gamma-interferon (Bovigam) assay. Vet.Microbiol. 2006;112(2-4):171-9.

[116] Waters WR, Nonnecke BJ, Olsen SC, Palmer MV. Effects of pre-culture holding time and temperature on interferon-gamma responses in whole blood cultures from Mycobacterium bovis-infected cattle. Vet.Microbiol. 2007;119(24):277-82. 
[117] Jungersen G, Mikkelsen H, Grell SN. Use of the johnin PPD interferongamma assay in control of bovine paratuberculosis.

Vet.Immunol.Immunopathol. in press.

[118] Wood PR, Jones SL. BOVIGAM: an in vitro cellular diagnostic test for bovine tuberculosis. Tuberculosis (Edinb) 2001;81(1-2):147-55.

[119] Sauzullo I, Mengoni F, Lichtner M, Massetti AP, Rossi R, lannetta M, et al. In vivo and in vitro effects of antituberculosis treatment on mycobacterial interferon-gamma T cell response. PLoS One 2009;4(4):e5187.

[120] Lee SW, Lee CT, Yim JJ. Serial interferon-gamma release assays during treatment of active tuberculosis in young adults. BMC Infect.Dis. 2010;10:300.

[121] Dean GS, Rhodes SG, Coad M, Whelan AO, Wheeler P, VillarealRamos B, et al. Isoniazid treatment of Mycobacterium bovis in cattle as a model for human tuberculosis. Tuberculosis (Edinb) 2008;88(6):586-94.

[122] Dyrhol-Riise AM, Gran G, Wentzel-Larsen T, Blomberg B, Haanshuus CG, Morkve O. Diagnosis and follow-up of treatment of latent tuberculosis; the utility of the QuantiFERON-TB Gold In-tube assay in outpatients from a tuberculosis low-endemic country. BMC Infect.Dis. 2010;10:57.

[123] Bocchino $M$, Chairadonna $P$, Matarese $A$, Bruzzese D, Salvatores $M$, Tronci M, et al. Limited usefulness of QuantiFERON-TB Gold In-Tube for monitoring anti-tuberculosis therapy. Respir.Med. 2010;104(10):1551-6.

[124] Sawyer J, Mealing D, Dalley D, Dave D, Lesellier S, Palmer S, et al. Development and evaluation of a test for tuberculosis in live European badgers (Meles meles) based on measurement of gamma interferon mRNA by real-time PCR. J.Clin.Microbiol. 2007;45(8):2398-403.

[125] Scott ME. The Impact of Infection and Disease on Animal Populations: Implications for Conservation Biology. Conserv.Biol. 1988;2(1):pp. 40-56.

[126] Clegg TA, Duignan A, Whelan C, Gormley E, Good M, Clarke J, et al. Using latent class analysis to estimate the test characteristics of the gammainterferon test, the single intradermal comparative tuberculin test and a multiplex immunoassay under Irish conditions. Vet.Microbiol. 2011;151(12):68-76.

[127] Waters WR, Palmer MV, Thacker TC, Bannantine JP, Vordermeier HM, Hewinson RG, et al. Early antibody responses to experimental Mycobacterium bovis infection of cattle. Clin.Vaccine Immunol. 2006;13(6):648-54.

[128] Lyashchenko KP, Greenwald R, Esfandiari J, Greenwald D, Nacy CA, Gibson S, et al. PrimaTB STAT-PAK assay, a novel, rapid lateral-flow test for tuberculosis in nonhuman primates. Clin.Vaccine Immunol. 2007;14(9):115864. 
[129] Harrington NP, Surujballi OP, Prescott JF, Duncan JR, Waters WR, Lyashchenko K, et al. Antibody responses of cervids (Cervus elaphus) following experimental Mycobacterium bovis infection and the implications for immunodiagnosis. Clin.Vaccine Immunol. 2008;15(11):1650-8.

[130] Lightbody KA, Skuce RA, Neill SD, Pollock JM. Mycobacterial antigenspecific antibody responses in bovine tuberculosis: an ELISA with potential to confirm disease status. Vet.Rec. 1998;142(12):295-300.

[131] Buddle BM, Ryan TJ, Pollock JM, Andersen P, de Lisle GW. Use of ESAT-6 in the interferon- $y$ test for diagnosis of bovine tuberculosis following skin testing. Veterinary Microbiology, 2001;80(1):37-46.

[132] Amadori M, Lyashchenko KP, Gennaro ML, Pollock JM, Zerbini I. Use of recombinant proteins in antibody tests for bovine tuberculosis. Vet.Microbiol. 2002;85(4):379-89.

[133] Pollock JM, Welsh MD, McNair J. Immune responses in bovine tuberculosis: towards new strategies for the diagnosis and control of disease. Vet.Immunol.Immunopathol. 2005;108(1-2):37-43.

[134] Martin-Atance P, Leon-Vizcaino L, Palomares F, Revilla E, GonzalezCandela M, Calzada J, et al. Antibodies to Mycobacterium bovis in wild carnivores from Donana National Park (Spain). J.Wildl.Dis. 2006;42(3):704-8.

[135] Lyashchenko KP, Greenwald R, Esfandiari J, Olsen JH, Ball R, Dumonceaux G, et al. Tuberculosis in elephants: antibody responses to defined antigens of Mycobacterium tuberculosis, potential for early diagnosis, and monitoring of treatment. Clin.Vaccine Immunol. 2006;13(7):722-32.

[136] Lyashchenko KP, Singh M, Colangeli R, Gennaro ML. A multi-antigen print immunoassay for the development of serological diagnosis of infectious diseases. J.Immunol.Methods 2000;242(1-2):91-100.

[137] O'Brien DJ, Schmitt SM, Lyashchenko KP, Waters WR, Berry DE, Palmer MV, et al. Evaluation of blood assays for detection of Mycobacterium bovis in white-tailed deer (Odocoileus virginianus) in Michigan. J.Wildl.Dis. 2009;45(1):153-64.

[138] Greenwald R, Esfandiari J, Lesellier S, Houghton R, Pollock J, Aagaard $\mathrm{C}$, et al. Improved serodetection of Mycobacterium bovis infection in badgers (Meles meles) using multiantigen test formats. Diagn.Microbiol.Infect.Dis. 2003;46(3):197-203.

[139] Waters WR, Stevens GE, Schoenbaum MA, Orloski KA, RobbeAusterman S, Harris NB, et al. Bovine tuberculosis in a nebraska herd of farmed elk and fallow deer: a failure of the tuberculin skin test and opportunities for serodiagnosis. Vet.Med.Int. 2011;2011:953985. 
[140] Lyashchenko KP, Greenwald R, Esfandiari J, Chambers MA, Vicente J, Gortazar C, et al. Animal-side serologic assay for rapid detection of Mycobacterium bovis infection in multiple species of free-ranging wildlife. Vet.Microbiol. 2008;132(3-4):283-92.

[141] Lyashchenko KP, Greenwald R, Esfandiari J, Meylan M, Burri IH, Zanolari P. Antibody responses in New World camelids with tuberculosis caused by Mycobacterium microti. Vet.Microbiol. 2007;125(3-4):265-73.

[142] Himsworth CG, Elkin BT, Nishi JS, Epp T, Lyashchenko KP, Surujballi $\mathrm{O}$, et al. Comparison of test performance and evaluation of novel immunoassays for tuberculosis in a captive herd of wood bison naturally infected with Mycobacterium bovis. J.Wildl.Dis. 2010;46(1):78-86.

[143] Greenwald R, Lyashchenko O, Esfandiari J, Miller M, Mikota S, Olsen $\mathrm{JH}$, et al. Highly accurate antibody assays for early and rapid detection of tuberculosis in African and Asian elephants. Clin.Vaccine Immunol. 2009;16(5):605-12.

[144] Brusasca PN, Peters RL, Motzel SL, Klein HJ, Gennaro ML. Antigen recognition by serum antibodies in non-human primates experimentally infected with Mycobacterium tuberculosis. Comp.Med. 2003;53(2):165-72.

[145] Aagaard C, Govaerts M, Meikle V, Vallecillo AJ, Gutierrez-Pabello JA, Suarez-Guemes F, et al. Optimizing antigen cocktails for detection of Mycobacterium bovis in herds with different prevalences of bovine tuberculosis: ESAT6-CFP10 mixture shows optimal sensitivity and specificity. J.Clin.Microbiol. 2006;44(12):4326-35.

[146] Chambers MA, Rogers F, Delahay RJ, Lesellier S, Ashford R, Dalley D, et al. Bacillus Calmette-Guerin vaccination reduces the severity and progression of tuberculosis in badgers. Proc.Biol.Sci. 2011;278(1713):191320.

[147] Waters WR, Palmer MV, Bannantine JP, Greenwald R, Esfandiari J, Andersen $\mathrm{P}$, et al. Antibody responses in reindeer (Rangifer tarandus) infected with Mycobacterium bovis. Clin.Diagn.Lab.Immunol. 2005;12(6):72735.

[148] Gallagher J, Monies R, Gavier-Widen M, Rule B. Role of infected, nondiseased badgers in the pathogenesis of tuberculosis in the badger. Veterinary Record 1998;142(26):710-4.

[149] Buddle BM, Wilson T, Denis M, Greenwald R, Esfandiari J, Lyashchenko KP, et al. Sensitivity, specificity, and confounding factors of novel serological tests used for the rapid diagnosis of bovine tuberculosis in farmed red deer (Cervus elaphus). Clin.Vaccine Immunol. 2010;17(4):626-30. 
[150] Whelan C, Shuralev E, O'Keeffe G, Hyland P, Kwok HF, Snoddy P, et al. Multiplex immunoassay for serological diagnosis of Mycobacterium bovis infection in cattle. Clin.Vaccine Immunol. 2008;15(12):1834-8.

[151] Shuralev E, Quinn P, Doyle M, Duignan A, Kwok HF, Bezos J, et al. Application of the Enfer chemiluminescent multiplex ELISA system for the detection of Mycobacterium bovis infection in goats. Vet.Microbiol. 2012;154(3-4):292-7.

[152] Green LR, Jones CC, Sherwood AL, Garkavi IV, Cangelosi GA, Thacker TC, et al. Single-Antigen Serological Testing for Bovine Tuberculosis. Clinical and Vaccine Immunology 2009;16(9):1309-13.

[153] Khan IH, Ravindran R, Yee J, Ziman M, Lewinsohn DM, Gennaro ML, et al. Profiling Antibodies to Mycobacterium tuberculosis by Multiplex Microbead Suspension Arrays for Serodiagnosis of Tuberculosis. Clinical and Vaccine Immunology 2008;15(3):433-8.

[154] Jolley ME, Nasir MS, Surujballi OP, Romanowska A, Renteria TB, De la Mora A, et al. Fluorescence polarization assay for the detection of antibodies to Mycobacterium bovis in bovine sera. Vet.Microbiol. 2007;120(1-2):113-21.

[155] Surujballi O, Lutze-Wallace C, Turcotte C, Savic M, Stevenson D, Romanowska A, et al. Sensitive diagnosis of bovine tuberculosis in a farmed cervid herd with use of an MPB70 protein fluorescence polarization assay. Can.J.Vet.Res. 2009;73(3):161-6.

[156] Chambers MA, Pressling WA, Cheeseman CL, Clifton-Hadley RS, Hewinson RG. Value of existing serological tests for identifying badgers that shed Mycobacterium bovis. Vet.Microbiol. 2002;86(3):183-9.

[157] Denis M, Keen DL, Neil Wedlock D, de Lisle GW, Buddle BM.

Susceptibility of brushtail possums (Trichosurus vulpecula) infected with Mycobacterium bovis is associated with a transient macrophage activation profile. Tuberculosis (Edinb) 2005;85(4):235-44.

[158] Waters WR, Palmer MV, Sacco RE, Whipple DL. Nitric oxide production as an indication of Mycobacterium bovis infection in white-tailed deer (Odocoileus virginianus). J.Wildl.Dis. 2002;38(2):338-43.

[159] Fend R, Geddes R, Lesellier S, Vordermeier H-, Corner LAL, Gormley $\mathrm{E}$, et al. Use of an electronic nose to diagnose Mycobacterium bovis infection in badgers and cattle. J.Clin.Microbiol. 2005;43(4):1745-51.

[160] Spooner AD, Bessant C, Turner C, Knobloch H, Chambers M. Evaluation of a combination of SIFT-MS and multivariate data analysis for the diagnosis of Mycobacterium bovis in wild badgers. Analyst 2009;134(9):19227. 
[161] Buddle BM, Livingstone PG, de Lisle GW. Advances in ante-mortem diagnosis of tuberculosis in cattle. N.Z.Vet.J. 2009;57(4):173-80.

[162] Kleeberg $\mathrm{HH}$. The tuberculin skin test in cattle. Journal of the South African Veterinary Association 1960;31:213-225.

[163] Christensen J, Gardner IA. Herd-level interpretation of test results for epidemiologic studies of animal diseases. Prev.Vet.Med. 2000;45(1-2):83106.

[164] Pollock JM, Girvin RM, Lightbody KA, Clements RA, Neill SD, Buddle $\mathrm{BM}$, et al. Assessment of defined antigens for the diagnosis of bovine tuberculosis in skin test-reactor cattle. Vet.Rec. 2000;146(23):659-65.

[165] Gardner IA, Stryhn H, Lind P, Collins MT. Conditional dependence between tests affects the diagnosis and surveillance of animal diseases. Prev.Vet.Med. 2000;45(1-2):107-22.

[166] Whelan C, Shuralev E, Kwok HF, Kenny K, Duignan A, Good M, et al. Use of a multiplex enzyme-linked immunosorbent assay to detect a subpopulation of Mycobacterium bovis-infected animals deemed negative or inconclusive by the single intradermal comparative tuberculin skin test. J.Vet.Diagn.Invest. 2011;23(3):499-503.

[167] Jaroso R, Vicente J, Martin-Hernando MP, Aranaz A, Lyashchenko K, Greenwald $R$, et al. Ante-mortem testing wild fallow deer for bovine tuberculosis. Vet.Microbiol. 2010;146(3-4):285-9.

[168] Berentsen AR, Dunbar MR, Johnson SR, Robbe-Austerman S, Martinez $\mathrm{L}$, Jones RL. Active use of coyotes (Canis latrans) to detect Bovine Tuberculosis in northeastern Michigan, USA. Vet.Microbiol. 2011;151(12):126-32.

[169] Rhodes SG, Gunn-Mooore D, Boschiroli ML, Schiller I, Esfandiari J, Greenwald R, et al. Comparative study of IFNy and antibody tests for feline tuberculosis. Vet.Immunol.Immunopathol. 2011;144(1-2):129-34.

[170] Drewe JA, Foote AK, Sutcliffe RL, Pearce GP. Pathology of Mycobacterium bovis infection in wild meerkats (Suricata suricatta). J.Comp.Pathol. 2009;140(1):12-24.

[171] Aurtenetxe O, Barral M, Vicente J, de la Fuente J, Gortazar C, Juste RA. Development and validation of an enzyme-linked immunosorbent assay for antibodies against Mycobacterium bovis in European wild boar. BMC Vet.Res. 2008;4:43.

[172] Thoen CO, Mills K, Hopkins MP. Enzyme-linked protein A: an enzymelinked immunosorbent assay reagent for detecting antibodies in tuberculous exotic animals. Am.J.Vet.Res. 1980;41(5):833-5. 
[173] Anonymous. Chapter 1.1.4/5 Principles and methods of validation of diagnostic assays for infectious diseases. Manual of diagnostic tests and vaccines for terrestrial animals: Office International des Epizooties (OIE); 2009.

[174] Jacobson $\mathrm{RH}$. Validation of serological assays for diagnosis of infectious diseases. Rev.Sci.Tech. 1998;17(2):469-86.

[175] Bossuyt PM, Reitsma JB, Bruns DE, Gatsonis CA, Glasziou PP, Irwig LM, et al. The STARD statement for reporting studies of diagnostic accuracy: explanation and elaboration. Clin.Chem. 2003;49(1):7-18.

[176] Hui SL, Walter SD. Estimating the error rates of diagnostic tests. Biometrics 1980;36(1):167-71.

[177] Branscum AJ, Gardner IA, Johnson WO. Estimation of diagnostic-test sensitivity and specificity through Bayesian modeling. Prev.Vet.Med. 2005;68(2-4):145-63.

[178] Toft N, Jorgensen E, Hojsgaard S. Diagnosing diagnostic tests: evaluating the assumptions underlying the estimation of sensitivity and specificity in the absence of a gold standard. Prev.Vet.Med. 2005;68(1):19-33.

[179] Alvarez J, Perez A, Bezos J, Marques S, Grau A, Saez JL, et al. Evaluation of the sensitivity and specificity of bovine tuberculosis diagnostic tests in naturally infected cattle herds using a Bayesian approach. Vet.Microbiol. 2012;155(1):38-43.

[180] Waters WR, Palmer MV, Thacker TC, Orloski K, Nol P, Harrington NP, et al. Blood culture and stimulation conditions for the diagnosis of tuberculosis in cervids by the Cervigam assay. Veterinary Record 2008;162(7):203-8.

[181] Gowtage-Sequeira S, Paterson A, Lyashchenko KP, Lesellier S, Chambers MA. Evaluation of the CervidTB STAT-PAK for the detection of Mycobacterium bovis infection in wild deer in Great Britain. Clin.Vaccine Immunol. 2009;16(10):1449-52.

[182] Boadella M, Lyashchenko K, Greenwald R, Esfandiari J, Jaroso R, Carta $\mathrm{T}$, et al. Serologic Tests for Detecting Antibodies against Mycobacterium Bovis and Mycobacterium Avium Subspecies Paratuberculosis in Eurasian Wild Boar (Sus Scrofa Scrofa). Journal of Veterinary Diagnostic Investigation 2011;23(1):77-83.

[183] Lyashchenko KP, Greenwald R, Esfandiari J, Rhodes S, Dean G, de la Rua-Domenech $R$, et al. Diagnostic value of animal-side antibody assays for rapid detection of Mycobacterium bovis or Mycobacterium microti infection in South American camelids. Clin.Vaccine Immunol. 2011;18(12):2143-7.

[184] Wernery U, Kinne J, Jahans KL, Vordermeier HM, Esfandiari J, Greenwald R, et al. Tuberculosis outbreak in a dromedary racing herd and 
rapid serological detection of infected camels. Vet.Microbiol. 2007;122(12):108-15.

[185] Parsons SD, Gous TA, Warren RM, de Villiers C, Seier JV, van Helden PD. Detection of Mycobacterium tuberculosis infection in chacma baboons (Papio ursinus) using the QuantiFERON-TB gold (in-tube) assay. J.Med.Primatol. 2009;38(6):411-7. 